\title{
Fuzzy-based multi-criteria decision analysis of environmental regulation and green economic efficiency in a post-COVID-19 scenario: the case of China
}

\author{
Shuangliang Yao ${ }^{1}$ \\ Received: 25 December 2020 / Accepted: 20 January 2021 / Published online: 16 February 2021 \\ (C) The Author(s), under exclusive licence to Springer-Verlag GmbH, DE part of Springer Nature 2021
}

\begin{abstract}
The COVID-19 pandemic outbreak posed serious threats not only to global health but also to the worldwide development regime. The experts, economists, policymakers, and the governments expressed their pledges and determinations to adapt and mitigate climate change. Policymakers and governments have started adopting green growth and development strategies. The progress moves further to achieve green economic efficiency (GEE) to achieve economic, social, and environmental development. One of the major challenges has been promulgating and strictly implementing environmental regulations and policies vis-à-vis green growth and development. China, having the second largest economy, has started its voyage to achieve GEE. However, there are multiple challenges on the way to the green economy. The objective of the present stud is to analyze environmental regulation and GEE in China using fuzzy-based multi-criteria decision analysis. To serve this purpose, the study identifies 5 alternative strategies to achieve GEE while considering 10 criteria and 48 sub-criteria in the context of environmental regulations in China. The Fuzzy Analytical Hierarchy Process (AHP) has been employed to rank criteria and sub-criteria to the goal. The Fuzzy VIekriterijumsko KOmpromisno Rangiranje (VIKOR) method has been used to rank the alternative strategies of GEE. The proposed model unveiled resource efficiency and green purchasing as the best strategy to achieve GEE in the Chinese economy followed by local production. The study provides a comprehensive insight into the green development process to achieve GEE in the Chinese economy in the post-COVID-19 world.
\end{abstract}

Keywords Environmental regulation · Green economic efficiency · Green economy · Post-COVID-19 · Fuzzy AHP · Fuzzy VIKOR

\section{Introduction}

In the wake of the Paris agreement and the global consensus on Sustainable Development Goals (SDGs) in 2015, the global economies have been focusing on the formulation and implementation of adaption and mitigation strategies (Ahmed et al. 2020a). However, economic development and environmental protection being contradictory objectives have become a major concern, especially for developing countries (Liu et al. 2020). Unprecedented rapid growth in developing economies

Responsible Editor: Philippe Garrigues

Shuangliang Yao

just_ysl@just.edu.cn

1 School of Economics and Management, Jiangsu University of Science and Technology, Zhenjiang 212003, China required resource inputs resulting in significant ecological damage (Miao et al. 2017). Promulgation and enforcement of environmental regulations have fundamental importance for eco-efficiency to balance the economic value and environmental consequences (Liu et al. 2020). The economists, policymakers, and economic decision-makers are convinced that the greening of economies is not a "drag on growth" but a new "engine of growth" (UNEP 2011). It provides a great opportunity and motivates the policymakers and the governments to enable conditions to stimulate transitions to a green economy.

Green Economic Initiative (GEI) was founded by the United Nations Environment Programme (UNEP) in 2008; it was aimed to improve "human well-being and social equity, while significantly reducing environmental risks and ecological scarcities" (UNEP 2011) and the green economy was defined as "one which is a low carbon, resource-efficient, and socially inclusive" (UNEP 2011). The concept of GEE is 
multi-dimensional and multi-faceted. It must be examined from the perspectives of a multi-criteria decision framework. As the economic efficiency is not only limited to GTI, its scope is beyond it, extending to every socio-economic activity in the economy. Recently, green economic efficiency (GEE) has attracted the attention of researchers and analysts. A recent study by Liu et al. (2020) traced out the causal relationships among environmental regulation, green technological innovation (GTI), and their interaction term on eco-efficiency in China. The study explores the impact of GDI on ecoefficiency under multiple environmental regulations to adjust and obtain the more marginal benefit of green technology. Based on the economic-social-resource-environment perspective, Wang et al. (2019) examine GEE in the Yangtze River Delta (YRD) using spatiotemporal evolution and influencing factors. The study unveiled that overall spatial pattern has emerged higher efficiency in the West but lower efficiency in the East. The biggest direct effect on local GEE and spatial spillover effects on nearby areas was found in terms of the proportion of tertiary industry. Though the study was primarily focused on environmental regulation, GTI and ecoefficiency yet did not cover the overall dynamics of environmental regulation and green economic efficiency (GEE) in China.

Global efforts were underway to combat the menace of climate change. It was considered to be a global climate challenge in the pre-COVID-19 world. The COVID-19 pandemic outbreak changed the overall scenario and diverted the attention of the policymakers and the governments toward an emergent and unprecedented global health crisis posed by a novel coronavirus. COVID-19 appeared as a development challenge for all countries, accentuating the case for a global development paradigm. The pandemic has implications across global value chains, digitalization, debt, and climate change (Oldekop et al. 2020). Efforts have been put to enhance the energy landscape and reduce air pollutions (Solangi et al. 2018). Global oil market crash and COVID-19 pandemic exerted economic and social issues that need to be addressed through thoughtful policy design (Henry et al. 2020). There is a dire need to be persistent in the efforts of mitigation and adaptation of climate change. Though the pandemic has affected the growth and development trajectories of the economy, yet an economic recovery tilted toward green stimulus and reduction in traditional fuel investment would add the positive outcomes in avoiding future global warming (Forster et al. 2020). The Chinese economy, being first hit by the COVID-19 pandemic, is focusing on economic recovery. The focus is on the stimulation of investment in infrastructure to facilitate renewable energy, intercity transport, and electric vehicle charging stations. Moreover, the Chinese government, in post-COVID-19 recovery, is focusing on five work streams - food, water and energy, urban climate adoption, circular economy, energy storage (Thorpe 2020). All of these areas are pivotal to achieve environmental regulation and GEE criteria and alternative strategies.

The objective of the paper is to assess and prioritize alternative strategies to achieve GEE in China in a post-COVID19 scenario. This study prioritizes 5 alternative strategies under 10 criteria and 48 sub-criteria in total. These criteria and sub-criteria are distilled through extensive literature review in environmental regulation and policy formulations for green economic development and green economic efficiency achievement in the Chinese economy. This study is a comprehensive analysis based on the fuzzy-based multi-criteria decision analysis. Firstly, the identified criteria and sub-criteria for green economic efficiency are assessed and ranked using the Fuzzy Analytical Hierarchy Process (AHP). Secondly, green economic efficiency strategies are evaluated and prioritized using the Fuzzy VIKOR ${ }^{1}$ method. Rankings of each criterion and sub-criteria are found based on Fuzzy AHP estimations. This ranking clarifies the important criteria and sub-criteria significant for green economic efficiency. Moreover, the Fuzzy VIKOR analysis provides the ranking of GEE alternative strategies in the context of prioritized criteria and subcriteria for the Chinese economy. The fuzzy-based multicriteria decision analysis for environmental regulation for green economic efficiency would provide guidelines in the post-COVID-19 scenario.

\section{Proposed criteria, sub-criteria, and alternative strategies to green economic efficiency}

The present study focuses on the examination and prioritization of strategies to GEE in China based on the fuzzy-based multi-criteria decision analysis of environmental regulations for GEE. Environmental regulation is an important fulcrum for the transition to green industrial growth (Feng and Chen 2018). The recent study provides a profound understanding by arguing that moderate environmental regulation can help reduce the damaging influence of green technological innovation (Liu et al. 2020). The primary focus of this study is to identify, assess, and prioritize the criteria and sub-criteria for alternative GEE strategies in China. This research determines a profound insight to achieve GEE in the post-COVID-19. To serve this purpose, the authors have carried out an extensive literature review to identify criteria and sub-criteria for GEE in China. The study finalized 10 major criteria including SocioEconomic Development Policies, Green Growth Agenda promulgated by the government, Green Industrial Development (GID), Environmental Regulations, Resource Efficiency, Technological Initiatives and Innovation (TII), Green

\footnotetext{
${ }^{1}$ VIKOR is an acronym for a Serbian term "VIekriterijumsko KOmpromisno Rangiranje" which implies "multi-criteria optimization and compromise solution" in English (Shumaiza et al. 2019).
} 
Energy Production and Consumption Practices, Blue-Green Infrastructure Development, Pollution Control, and Waste Management, and Labor Policies. The sub-criteria for each criterion with a brief description are presented in Table 1.

\section{Green economic efficiency strategies}

The present study identifies $5 \mathrm{GE}$ strategies. The alternative strategies and their brief descriptions are summarized in Table 2 .

Since globally, many countries have traditional environmental regulations and economic efficiency system, which negatively impacts the environment, such as global warming, climate change, air pollution, and human health (such as COVID19). In this regard, it is important to transform the old-style environmental and economic efficiencies into a sustainable environmental and economic efficiency system. In this study, a comprehensive literature review was analyzed to identify the most relevant GEE criteria, sub-criteria, and strategies. Thus, 10 GEE criteria, 48 sub-criteria, and 5 significant strategies have been identified in the context of China. This study used a fuzzybased multi-criteria decision model, i.e., Fuzzy AHP and Fuzzy VIKOR, to evaluate this decision-making problem. This is the first study that analyzed GEE criteria, sub-criteria, and strategies using a fuzzy decision model. This research would assist the government and decision-makers in implementing environmental regulation and GEE in obtaining green development in China. This would also help boost Chinese economy in the post-COVID-19 scenario.

\section{Proposed fuzzy multi-criteria decision analysis}

The objective of this study is to select, analyze, and rank the GEE criteria, sub-criteria, and alternative strategies in the context of Chinese economy. In this regard, the fuzzy-based multi-criteria decision analysis, i.e., AHP and VIKOR methods, has been used to solve this multi-faceted decisionmaking problem. The AHP and VIKOR are the most utilized and suitable approaches to MCDA. Figure 1 shows the proposed fuzzy decision model. The sub-sections provided Fuzzy AHP and Fuzzy VIKOR methods to evaluate the proposed decision-making problem.

\section{Fuzzy AHP method}

The AHP method was proposed by Saaty in the 1970s (Saaty 1990; Wang et al. 2020). This approach is very famous and useful in analyzing and prioritizing any decision-making problem. The AHP method has four hierarchical stages: goal, criteria, sub-criteria, and alternatives (Solangi et al. 2019b). This study used the Fuzzy AHP technique to obtain more reliable and robust results. Because fuzzy set theory helps in minimizing any human error and ambiguity during decisionmaking. In this study, the fuzzy-based pairwise comparison matrix has been operated as triangular fuzzy numbers (TFNs) to evaluate the GEE criteria and sub-criteria for environmental sustainability in China. The linguistic terms based on TFNs are shown in Table 3 (Kaganski et al. 2018).

The following steps have been used to compute the inconsistency ratio of the fuzzy pairwise comparison matrix, which is proposed by Gogus and Boucher (1998).

Step 1. Convert a triangular fuzzy matrix into two independent matrices:

$X_{i}=\left(l_{i}, m_{i}, u_{i}\right)$

Next, the first triangular fuzzy matrix is established with the middle fuzzy triangular matrix:

$X_{m}=\left[x_{i j m}\right]$

Here, the second triangular fuzzy matrix is established by a geometric mean approach for the upper and lower bounds of the TFNs:

$X_{g}=\left[\sqrt{x_{i j u} x_{i j l}}\right]$

Step 2. Establish the weight vector based on the Saaty method and computation of lambda max.

Step 3. Establish the consistency index (CI) for each matrix:

$C I_{m}=\frac{\lambda_{\max }^{m}-n}{n-1}$
$C I_{g}=\frac{\lambda_{\max }^{g}-n}{n-1}$

Step 4. Establish the consistency ratio (CR) for each matrix. For $\mathrm{CR}$, the consistency index (CI) of each matrix is divided by its random index (RI).

$C R_{m}=\frac{C I_{m}}{R I_{m}}$
$C R_{g}=\frac{C I_{g}}{R I_{g}}$

The fuzzy matrices are to be considered valid if the values of $C R_{m}$ and $C R_{g}$ are smaller than 0.10 . However, if the value surpasses 0.10 , then it will be considered inconsistent. The RI scale is shown in Table 4. The RI scale of the current study is proposed by Gogus and Boucher (Zhou et al. 2019).

\section{Fuzzy VIKOR method}

The VIKOR method was proposed by Opricovic in 1980 (Opricovic and Tzeng 2007). This approach mainly focuses 
Table 1 Criteria and sub-criteria and strategies to green economic efficiency

\begin{tabular}{lll}
\hline Code & Criteria & Sub-criteria \\
\hline A1 & $\begin{array}{c}\text { Socio-Economic } \\
\text { Development Policies }\end{array}$ & $\begin{array}{c}\text { Sustainable Development } \\
\text { Initiative (SDI) }\end{array}$
\end{tabular}
Development Policies Initiative (SDI)

Green Civil Society (GCS) Initiative(s)

Ensuring Stakeholder
Participation

Gender Mainstreaming

Sectoral and Regional Development Initiatives

Social Inclusion in Green Economy

B2 Green Growth Agenda

Inclusive and Collaborative Planning

Promote Green Growth Patterns (GGPs)

Simulate Green Investment

Government Investment Incentives (GIIs)

Sustainable Special Economic Zone (SSEZs) Development

\section{C3 Green Industrial} Development

Green Product Innovation (GPI)
Code Brief description

A11 SDI policy regimes can stimulate the process of green development and increase GEE. Improvement in the community's quality of life attracts a stronger workforce (Hou et al. 2019). Moreover, the increase in the local production of goods and services is also significant to achieve the objective (ICMA 2019). The Chinese government has initiated Agenda 2030 for the adoption and implementation of SDGs in China (Yu et al. 2020). In addition to this, the Chinese government has introduced a new policy paradigm of "ecological civilization" (Tracy et al. 2017).

A12 The emergence of the green public sphere in the economic growth and development process plays a pivotal role in environmental protection (Yang and Calhoun 2007). The GCS has been growing fast and playing its positive role in combating environmental degradation and climate change (Fengshi 2009; Yang and Calhoun 2007).

A13 The participation of stakeholders and their role in developing a stable modern society is indispensable (Laurisz 2019). Stakeholder participation is beneficial in sustainable development (Weng et al. 2015; Zhuang 2017).

A14 The objectives of sustainable development cannot be achieved until the mainstreaming of gender into economic development policies and projects. The development should offer more equal opportunities for both men and women in development (Bohong et al. 2016).

A15 Sectoral and regional development initiatives need to be introduced to ensure sustainable and green development in the economy. Though the Chinese economy has shown tremendous growth, yet initiatives are required to address the regional development strategy among the Eastern, Central, and Western regions in China (Chu et al. 2018; Weng et al. 2015).

A16 In addition to the adoption of green stimulus for industries, investment in green projects, and other development initiatives, social inclusion indispensable in achieving the green economy objectives (IIED 2020; Weng et al. 2015).

B21 Inclusive and collaborative planning is fundamental to the development process (Ahmed et al. 2020b; Ali et al. 2019). In addition to this, communicative planning could help avoid conflicts during the development process (Wang and Wang 2020).

B22 The promotion of GGPs is pivotal for green economy efficiency. The Chinese government has been focusing on adopting GGPs (Weng et al. 2015).

B23 Green investment is critical for GEE. If the Chinese government attracts the green inward FDI and invests in foreign technology-intensive industries, it will be helpful to obtain green technology spillovers and stimulate green innovation (Luo et al. 2021).

B24 It is essential to provide direct government funding and tax incentives to promote green technology innovation. Moreover, it is also important to introduce some tax incentives to support green technology initiatives (Guo et al. 2018).

B25 The establishment of SSEZs is fundamental for setting up an eco-friendly industrial base in the economy. Apart from the other factors in developing SSEZs, sustainability issues under the Zone 3.0 paradigm are indispensable to achieve SDGs (Ahmed et al. 2020b).

C31

GPI refers to the product innovation that fulfills environmental requirements through innovation in design, development, and production through the product life cycle (Feng and Chen 2018). It plays a pivotal role in setting the green growth trajectory of the economy. In GPI, mostly, the focus is on the reduction of energy consumption (Chan et al. 2016; Feng and Chen 2018). 
Table 1 (continued)

Code Criteria Sub-criteria Code Brief description

GCI refers to the "innovation of production technology and technological equipment in the production process" (Feng and Chen 2018). It is believed that the increase in technical transformation investment of the total output value increases the GCI ability in the economy (Feng and Chen 2018).

Green Innovation Initiative (GII) for Green Industrial Growth (GIG)

Industrial Specialization

Industrial Diversity

Industrial Competition

D4 Environmental Regulations Minimization of Environmental
Risk

Market-based Environmental Regulations (MERs)

Monitoring and Evaluation System Development

Public Participation in Environmental Regulation and Compliance

Land/Planning laws

Sustainable Public Procurement (SPP)

Reducing Waste through Industrial Symbiosis

Reduce Resources and Energy Consumption

Efficient Land Use

F6 Technological Initiatives and Innovation
Direct Government Funding and Tax Incentives
C33 It is beneficial to decouple economic growth from the use and consumption of natural resources and energy. Moreover, it is also important to provide more value with better economic and ecological efficiency. The government's support is indispensable in encouraging green innovation for GIG (UNIDO 2010). Green innovation is also important in realizing sustainable development (Luo et al. 2021).

C34 Industrial specialization is conducive to economic growth (Ma et al. 2019).

C35 Industrial diversity is also an important factor in promoting innovation and productivity (Ma et al. 2019).

C36 Industrial competition is conducive to improving capital productivity (Ma et al. 2019).

D41 The AERs refer to the mandatory environmental laws, regulations, and policies promulgated and enacted by the government and government's environmental protection agencies. The Chinese government has introduced multiple AERs to ensure environmental protection (Feng and Chen 2018).

D42 MERs refer to sewage charges, subsidies, and tradable permits to prevent environmental damage and reduce pollution. The Chinese government has also introduced multiple MERs to protect the environment (Feng and Chen 2018).

D43 Monitoring and evaluating system development are critical in setting growth and development. The Chinese government has focused on "strengthening cross-departmental coordination of environmental monitoring and local management system" (Weng et al. 2015).

D44 Public participation environmental regulations are introduced to ensure public participation in environmental regulation activities through understanding information and compliance with environmental regulations (Feng and Chen 2018).

D45 Land use policies are a fundamental part of the policy mix to achieve economic, environmental, and social goals. Land use policies must ensure the cooperation between stakeholders at the local, regional, and national levels (OECD 2020).

E51 Minimization of environmental risks is one of the key objectives of the governments. It is critical to minimize the environmental risks posed by the industries, companies, and other business units in the economy. The Chinese government has introduced multiple policy instruments to manage environmental risks (Weng et al. 2015).

E52 The SPP is a driver for resource efficiency (Green Growth 2018)

E53 Resource efficiency can be obtained through a reduction in waste through industrial symbiosis. It has been achieved in Japan (Green Growth 2018).

E54 In the wake of the Paris agreement and the global community's consensus on SDGs in 2015, global efforts are underway to reduce resource and energy consumption and control carbon emissions. In the last 20 years, the Chinese government has put forward serious efforts to reduce energy intensity (Liao and Wang 2019).

E55 Efficient use of land is important. The Chinese government has introduced multiple projects to ensure efficient land use (Weng et al. 2015).

F61 Technological progress increases energy efficiency, reduces energy consumption, and has rebound effects and helps in energy saving (Liao 
Table 1 (continued)

\begin{tabular}{lll}
\hline Code Criteria & Sub-criteria & Code Brief description \\
\hline
\end{tabular}

Intellectual Property Laws

Research and Development (R\&D)

Green Technology Innovation

Marketization Innovation

G7

Green Energy Production Green Energy Initiative and Consumption

Practices

Energy-Saving Technology Adoption

Green Energy Transmission and Distribution System

Blue-Green Infrastructure Blue Infrastructure Development Development

Air Pollution Control

Wastewater Management

Solid Waste Management (SWM)

Green Stormwater Management System Development

Recycling Infrastructure

Transport Infrastructure and Wang 2019). It is vital to introduce direct government funding and tax incentives to promote technological initiatives and innovation programs.

F62 Protection of intellectual property rights is the critical element to stimulation technological progress and innovation. Promulgation of intellectual property laws and their implementation paves the way for technological innovation. The Chinese government has been focusing on this issue and continuously introduced intellectual property laws and regulations (Prud'homme and Zhang 2019).

F63 Promotion of R\&D is fundamental in achieving a green economy (Weng et al. 2015).

F64 Green innovation is pivotal for the transition to green industrial growth (Cao et al. 2019).

F65 Marketization innovation is also important. The intervention policies from the central/provincial governments independently stimulate the adoption of marketization innovation (Zhu and Zhang 2019).

G71 In the wake of the Paris agreement, governments worldwide have introduced green energy initiatives to reduce energy consumption and shift their energy mix from traditional to renewable energy sources (Kul et al. 2020). The Chinese economy has done impressively well in green energy production and consumption (Liao and Wang 2019).

G72 In addition to the production and consumption of clean energy, it is also vital to reduce energy consumption through energy-saving technology adoption (Hesselink and Chappin 2019).

G73 Efficient transmission and distribution of green energy are important. The Chinese government has put forward reform plans for the electric power system to reduce power transmission barriers (GTR 2018).

H81 Blue-green infrastructure (BGI) is increasingly attracting attention as an alternative to conventional water management. The efforts are underway to effective Blue infrastructure development in China (Liu et al. 2019).

H84 Transport infrastructure and its efficient use are critical for economic efficiency (Ma et al. 2019).

H85 The development and promotion of green buildings are significant in achieving SDGs. Chinese green building industry is growing fast $(\mathrm{Fu}$ et al. 2020) and will play a pivotal role in obtaining GEE. Moreover, urban green infrastructure has been given special attention in urban development planning and projects in China (Z. Zhu et al. 2019a).

I91 Environmental protection laws are important for green economic development. The Chinese government formulated and enacted the "Air Pollution Prevention and Control Law of the PRC" (Guo et al. 2018).

I92 Treatment of wastewater influent, sewage treatment, and water recycling are also important to pollution control and resource management. The Chinese government has put forward policy interventions to ensure sustainable water quality, maximizing energy recovery, efficient resource recycling, and environmental friendliness (Qu et al. 2019).

I93 SWM is one of the challenges for governments and societies. Efforts are needed to reach a zero-waste economy. It can be obtained through innovative technologies to reduce waste streams, increasing recycling 
Table 1 (continued)

\begin{tabular}{|c|c|c|c|c|}
\hline Code & Criteria & Sub-criteria & Code & Brief description \\
\hline & & & & $\begin{array}{l}\text { rates, transforming W2E without relying on incineration (Ali Shah } \\
\text { et al. 2020). }\end{array}$ \\
\hline & & $\begin{array}{l}\text { Shared and Circular Economy } \\
\text { Promotion }\end{array}$ & I94 & $\begin{array}{l}\text { The concept of a shared and circular economy has got attention all over } \\
\text { the globe. The Chinese government has taken initiatives to adopt and } \\
\text { promote a shared and circular economy in the country (Pesce et al. } \\
\text { 2020; Zhu et al. 2019b). }\end{array}$ \\
\hline \multirow[t]{4}{*}{$\mathrm{J} 10$} & Labor Policies & Skill Development & J101 & $\begin{array}{l}\text { Labor policies need to ensure investment in skills required for a } \\
\text { sustainable and low-carbon economy (ILO 2011). }\end{array}$ \\
\hline & & $\begin{array}{l}\text { Occupational Safety and Health } \\
\text { (OSH) }\end{array}$ & J102 & $\begin{array}{l}\text { Insurance of occupational safety and health is also fundamental on the } \\
\text { way to sustainable development (ILO 2011). }\end{array}$ \\
\hline & & SME Development & J103 & $\begin{array}{l}\text { The development of SMEs can help ensure green jobs due to the } \\
\text { labor-intensive (Ali 2013) and the environmentally friendly nature of } \\
\text { SMEs (ILO 2011). }\end{array}$ \\
\hline & & Green Jobs & J104 & $\begin{array}{l}\text { Sustainable development encompasses economic growth, sustaining } \\
\text { environmental quality, and improving human health, social justice, and } \\
\text { employment (Pociovălișteanu et al. 2015). Green jobs refer to "the } \\
\text { transformation of economies, enterprises, workplaces and labor marke } \\
\text { into a sustainable, low-carbon economy providing decent work" (ILO } \\
\text { 2015). }\end{array}$ \\
\hline
\end{tabular}

on ranking the set of alternatives with conflicting criteria to obtain compromise solutions. This approach will help decision-makers reach a mutual consensus (Liu et al. 2013). This study utilized a fuzzy-based VIKOR method to obtain more significant and reliable findings, even with less information, vague, and uncertain. The fuzzy set theory was developed by Zedah who proposed it in 1965 (Solangi et al. 2019a). There are several triangular fuzzy numbers (TFNs) that can be used for various purposes based on the decisionmaking problem (Shukla et al. 2014).

Table 2 Green economic efficiency alternative strategies

\begin{tabular}{|c|c|c|}
\hline Code & Strategy & Brief description \\
\hline $\mathrm{S} 1$ & $\begin{array}{l}\text { Green economic development } \\
\text { strategy }\end{array}$ & $\begin{array}{l}\text { The economies are industrializing by going green, using smart and innovation-driven ideas (Cao et al. } \\
\text { 2019). Economic growth and development are the primary objectives to achieve. In the green economy, } \\
\text { like traditional economic development, strategies are adapted for growth and development that improve } \\
\text { environmental outcomes (ICMA 2019). }\end{array}$ \\
\hline $\mathrm{S} 2$ & $\begin{array}{l}\text { Resource efficiency and green } \\
\text { purchasing strategy }\end{array}$ & $\begin{array}{l}\text { The green economic development strategies focus on production supply. Resource efficiency and green } \\
\text { purchasing are broader strategies that address the consumption side of the green economy. These } \\
\text { strategies harness the community's purchasing power, demand for energy, resources, water, and green } \\
\text { products (ICMA 2019). }\end{array}$ \\
\hline S3 & $\begin{array}{l}\text { Local production and utilization } \\
\text { strategy }\end{array}$ & $\begin{array}{l}\text { Local production and utilization strategy is another alternative to green development strategy. It encourages } \\
\text { an increase in community wealth by producing and consuming locally. It promotes regional self-reliance } \\
\text { and economic security. It also eliminates the environmental impacts linked to transportation and logistics } \\
\text { (ICMA 2019; OECD 2012). }\end{array}$ \\
\hline S4 & Waste stream management strategy & $\begin{array}{l}\text { This strategy primarily focuses on the adoption of aggressive solid waste management programs. It focuses } \\
\text { on reducing the costs and negative externalities related to waste disposal. The local governments can do } \\
\text { impressively by creating jobs and reducing the cost of doing business. However, for this purpose to } \\
\text { achieve, innovative technologies need to be introduced for a reduction in the waste stream, an increase in } \\
\text { recycling, and transforming W2E (ICMA 2019). }\end{array}$ \\
\hline S5 & Green infrastructure strategy & $\begin{array}{l}\text { Green infrastructure development strategy is another alternative to achieve GEE (John et al. 2019). } \\
\text { Comprehensive and inclusive land use policy decisions can significantly help inefficient resource use, } \\
\text { maintain environmental quality, and create economic activity. Moreover, local governments can } \\
\text { positively impact the green economy by using their authority in planning and implementing. The local } \\
\text { governments can help improve the quality of life for the residents and improve the local business } \\
\text { environment (ICMA 2019). }\end{array}$ \\
\hline
\end{tabular}


Fig. 1 The proposed fuzzy-based multi-criteria decision model

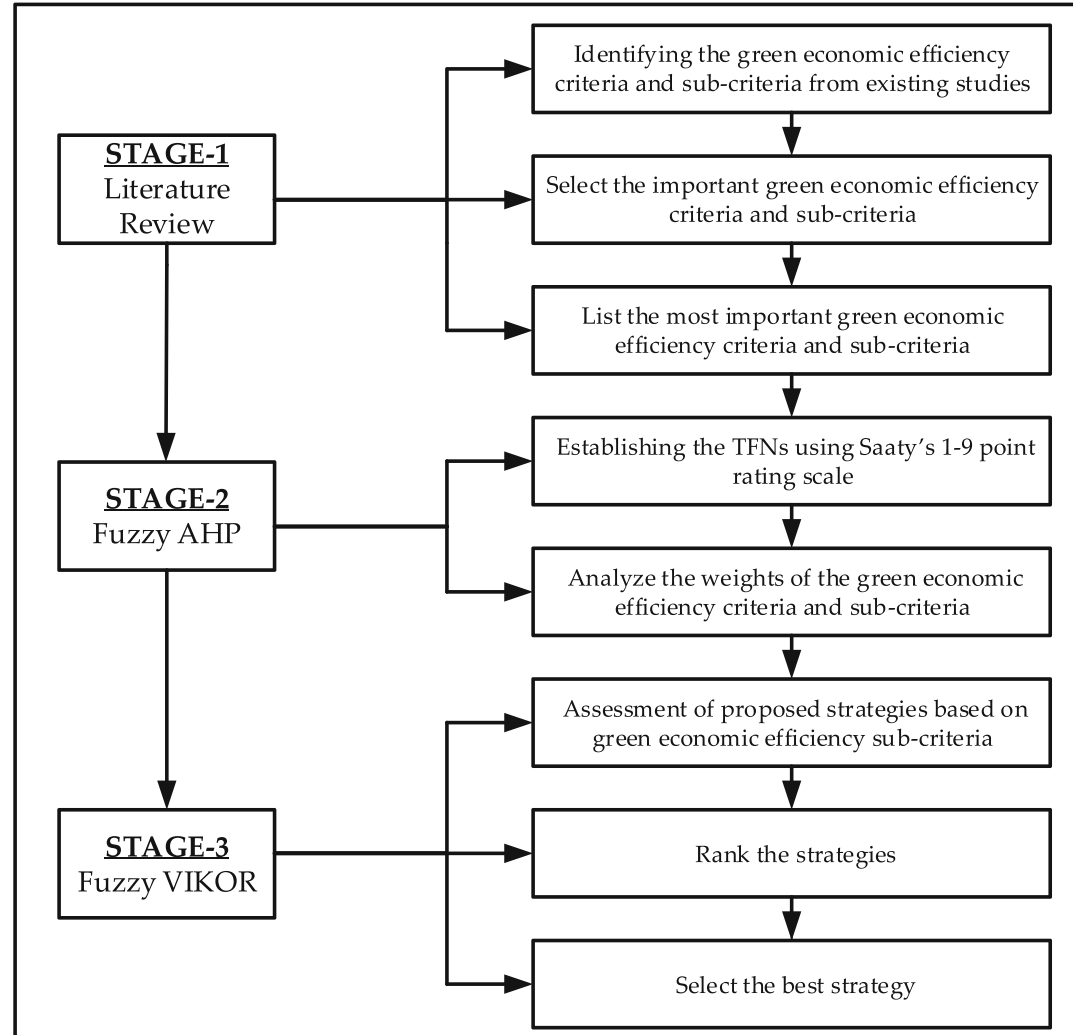

The followings are the key steps of the Fuzzy VIKOR method:

\section{Step 1. Create a decision matrix}

In this study, 48 sub-criteria and 5 alternatives are ranked based on the Fuzzy VIKOR method. Table 5 shows the type of criterion and weight assigned to each criterion.

The TFN scale of this study is presented in Table 6 .

The alternatives in terms of various criteria are evaluated, and the results of the decision matrix are shown in Appendix 2 Table 22.

Table 3 TFN scale

\begin{tabular}{lll}
\hline Code & Linguistic terms & TFNs \\
\hline 1 & Equally dominant & $(1,1,1)$ \\
2 & Equally to average dominant & $(1,2,3)$ \\
3 & Averagely dominant & $(2,3,4)$ \\
4 & Averagely to strongly dominant & $(3,4,5)$ \\
5 & Strongly dominant & $(4,5,6)$ \\
6 & Strongly to very strongly dominant & $(5,6,7)$ \\
7 & Very strongly dominant & $(6,7,8)$ \\
8 & Very strongly to extremely dominant & $(7,8,9)$ \\
9 & Extremely dominant & $(9,9,9)$ \\
\hline
\end{tabular}

Step 2. Determine the positive ideal solution and negative ideal solution

Positive and negative ideal solutions of each criterion can be obtained as follows.

If the criterion is positive, the positive ideal solution $\left(\widetilde{f}^{*}\right)$ and negative ideal solution $\left(\widetilde{f}^{\circ}\right)$ can be obtained using the following relations:

$\widetilde{f}_{\mathrm{j}}^{*}=\max _{i} \widetilde{f}_{i j} \quad \mathrm{i}=1,2, \ldots, \mathrm{n}$

Table 4 RI scale

\begin{tabular}{lll}
\hline$n$ & $R I_{m}$ & $R I_{g}$ \\
\hline 1 & 0 & 1 \\
2 & 0 & 2 \\
3 & 0.4890 & 0.1796 \\
4 & 0.7937 & 0.2627 \\
5 & 1.0720 & 0.3597 \\
6 & 1.1996 & 0.3818 \\
7 & 1.2874 & 0.4090 \\
8 & 1.3410 & 0.4164 \\
9 & 1.3793 & 0.4348 \\
10 & 1.4095 & 0.4455 \\
\hline
\end{tabular}


Table 5 Characteristics of criteria

\begin{tabular}{|c|c|c|c|}
\hline Number & Name & Type & Weight \\
\hline 1 & A11 & Benefit & $(0.021,0.021,0.021)$ \\
\hline 2 & A12 & Benefit & $(0.021,0.021,0.021)$ \\
\hline 3 & A13 & Benefit & $(0.021,0.021,0.021)$ \\
\hline 4 & A14 & Benefit & $(0.021,0.021,0.021)$ \\
\hline 5 & A15 & Benefit & $(0.021,0.021,0.021)$ \\
\hline 6 & A16 & Benefit & $(0.021,0.021,0.021)$ \\
\hline 7 & $\mathrm{~B} 21$ & Benefit & $(0.021,0.021,0.021)$ \\
\hline 8 & $\mathrm{~B} 22$ & Benefit & $(0.021,0.021,0.021)$ \\
\hline 9 & $\mathrm{~B} 23$ & Benefit & $(0.021,0.021,0.021)$ \\
\hline 10 & B24 & Benefit & $(0.021,0.021,0.021)$ \\
\hline 11 & B25 & Benefit & $(0.021,0.021,0.021)$ \\
\hline 12 & $\mathrm{C} 31$ & Benefit & $(0.021,0.021,0.021)$ \\
\hline 13 & $\mathrm{C} 32$ & Benefit & $(0.021,0.021,0.021)$ \\
\hline 14 & $\mathrm{C} 33$ & Benefit & $(0.021,0.021,0.021)$ \\
\hline 15 & $\mathrm{C} 34$ & Benefit & $(0.021,0.021,0.021)$ \\
\hline 16 & $\mathrm{C} 35$ & Benefit & $(0.021,0.021,0.021)$ \\
\hline 17 & $\mathrm{C} 36$ & Benefit & $(0.021,0.021,0.021)$ \\
\hline 18 & D41 & Benefit & $(0.021,0.021,0.021)$ \\
\hline 19 & D42 & Benefit & $(0.021,0.021,0.021)$ \\
\hline 20 & D43 & Benefit & $(0.021,0.021,0.021)$ \\
\hline 21 & D44 & Benefit & $(0.021,0.021,0.021)$ \\
\hline 22 & D45 & Benefit & $(0.021,0.021,0.021)$ \\
\hline 23 & E51 & Benefit & $(0.021,0.021,0.021)$ \\
\hline 24 & E52 & Benefit & $(0.021,0.021,0.021)$ \\
\hline 25 & E53 & Benefit & $(0.021,0.021,0.021)$ \\
\hline 26 & E54 & Benefit & $(0.021,0.021,0.021)$ \\
\hline 27 & E55 & Benefit & $(0.021,0.021,0.021)$ \\
\hline 28 & F61 & Benefit & $(0.021,0.021,0.021)$ \\
\hline 29 & F62 & Benefit & $(0.021,0.021,0.021)$ \\
\hline 30 & F63 & Benefit & $(0.021,0.021,0.021)$ \\
\hline 31 & F64 & Benefit & $(0.021,0.021,0.021)$ \\
\hline 32 & F65 & Benefit & $(0.021,0.021,0.021)$ \\
\hline 33 & G71 & Benefit & $(0.021,0.021,0.021)$ \\
\hline 34 & G72 & Benefit & $(0.021,0.021,0.021)$ \\
\hline 35 & G73 & Benefit & $(0.021,0.021,0.021)$ \\
\hline 36 & H81 & Benefit & $(0.021,0.021,0.021)$ \\
\hline 37 & $\mathrm{H} 82$ & Benefit & $(0.021,0.021,0.021)$ \\
\hline 38 & $\mathrm{H} 83$ & Benefit & $(0.021,0.021,0.021)$ \\
\hline 39 & $\mathrm{H} 84$ & Benefit & $(0.021,0.021,0.021)$ \\
\hline 40 & H85 & Benefit & $(0.021,0.021,0.021)$ \\
\hline 41 & I91 & Benefit & $(0.021,0.021,0.021)$ \\
\hline 42 & I92 & Benefit & $(0.021,0.021,0.021)$ \\
\hline 43 & $\mathrm{I} 93$ & Benefit & $(0.021,0.021,0.021)$ \\
\hline 44 & I94 & Benefit & $(0.021,0.021,0.021)$ \\
\hline 45 & $\mathrm{~J} 101$ & Benefit & $(0.021,0.021,0.021)$ \\
\hline 46 & J102 & Benefit & $(0.021,0.021,0.021)$ \\
\hline 47 & J103 & Benefit & $(0.021,0.021,0.021)$ \\
\hline 48 & $\mathrm{~J} 104$ & Benefit & $(0.021,0.021,0.021)$ \\
\hline
\end{tabular}

Table 6 TFN scale

\begin{tabular}{lll}
\hline Code & Linguistic terms & TFNs \\
\hline 1 & Very low & $(0,0,0.25)$ \\
2 & Low & $(0,0.25,0.5)$ \\
3 & Medium & $(0.25,0.5,0.75)$ \\
4 & High & $(0.5,0.75,1)$ \\
5 & Very high & $(0.75,1,1)$ \\
\hline &
\end{tabular}

If the criterion is negative, the positive ideal solution $\left(\widetilde{f}^{*}\right)$ and negative ideal solution $\left(\widetilde{f}^{\circ}\right)$ can be obtained using the following relations:

$\widetilde{f}_{\mathrm{j}}^{*}=\min _{i} \widetilde{f}_{i j} \mathrm{i}=1,2, \ldots, \mathrm{n}$

$\widetilde{f}_{\mathrm{j}}^{\circ}=\max _{i} \widetilde{f}_{i j} \mathrm{i}=1,2, \ldots, \mathrm{n}$

Step 3. Compute the normalized decision matrix

Based on the positive and negative ideal solutions, a normalized decision matrix can be calculated by the following relation:

$\widetilde{d}_{i j}=\left(\widetilde{f}_{j}^{*} \ominus \widetilde{f}_{i j}\right) /\left(r_{j}^{*}-l_{j}^{\circ}\right)$ Positive ideal solution

$\widetilde{d}_{i j}=\left(\widetilde{f}_{i j} \ominus \widetilde{f}_{j}^{*}\right) /\left(r_{j}^{\circ}-l_{j}^{*}\right)$ Negative ideal solution

where

$\widetilde{f}_{\mathrm{j}}^{*}=\left(l_{j}^{*}, m_{j}^{*}, r_{j}^{*}\right)$

$\widetilde{f}_{\mathrm{j}}^{\circ}=\left(l_{j}^{\circ}, m_{j}^{\circ}, r_{j}^{\circ}\right)$

Appendix 2 Table 23 shows the normalized values of the evaluation matrix.

Step 4. Compute the values $\widetilde{S}_{i}$ and $\widetilde{R}_{i}$ :

First, the normalized matrix is transformed into a weighted normalized decision matrix, and then the values $\widetilde{S}_{i}$ and $\widetilde{R}_{i}$ can be calculated as follows:

$$
\text { If } \widetilde{R}_{\mathrm{i}}=\left(R_{i}^{l}, R_{i}^{m}, R_{i}^{r}\right) \text { and } \widetilde{s}_{\mathrm{i}}=\left(s_{i}^{l}, s_{i}^{m}, s_{i}^{r}\right)
$$

$\widetilde{S}_{i}=\sum_{j=1}^{\mathrm{J}}\left(\widetilde{w}_{j} \otimes \widetilde{d}_{i j}\right)$ 
Table 7 The final ranking of GEE criteria

\begin{tabular}{llll}
\hline Code & Criteria & Weight & Rank \\
\hline A1 & Socio-Economic Development Policies & 0.161 & 1 \\
B2 & Green Growth Agenda & 0.120 & 3 \\
C3 & Green Industrial Development & 0.124 & 2 \\
D4 & Environmental Regulations & 0.113 & 4 \\
E5 & Resource Efficiency & 0.106 & 5 \\
F6 & Technological Initiatives and Innovation & 0.094 & 6 \\
G7 & Green Energy Production and Consumption Practices & 0.086 & 7 \\
H8 & Blue-Green Infrastructure Development & 0.076 & 8 \\
I9 & Pollution Control and Waste Management & 0.067 & 9 \\
J10 & Labor Policies & 0.052 & 10 \\
\hline
\end{tabular}

$\widetilde{R}_{i}=\max _{j}\left(\widetilde{w}_{j} \otimes \widetilde{d}_{i j}\right)$

Step 5. Calculate the VIKOR index $(Q)$

The value of $Q$ can be calculated as follows. If $\widetilde{Q}_{\mathrm{i}}=\left(Q_{i}^{l}, Q_{i}^{m}, Q_{i}^{r}\right)$

$\widetilde{\mathrm{Q}}_{\mathrm{i}}=v \frac{\left(\widetilde{s}_{i} \ominus \widetilde{s}^{*}\right)}{s^{{ }^{r}-s^{* l}}} \oplus(1-v) \frac{\left(\widetilde{R}_{i} \ominus \widetilde{R}^{*}\right)}{R^{o r}-R^{* l}}$

where

$\widetilde{s}^{*}=\min _{i} \widetilde{s}_{i}$

$s^{\circ} r=\max _{i} s_{i}^{r}$

$\widetilde{R}^{*}=\min _{i} \widetilde{R}_{i}$

$R^{\circ} r=\max _{i} R_{i}^{r}$
The variable $v$ representing the maximum group utility is equal to 0.5 in this study.

The fuzzy numbers $S, R$, and $Q$ can be transformed into crisp numbers using the following formula.

If $\widetilde{A}=(1, \mathrm{~m}, \mathrm{r}) \quad(\widetilde{A}$ is expressed as a fuzzy number $)$

$\operatorname{Crisp}(\widetilde{A})=\frac{2 m+l+r}{4}$

Appendix 2 Table 24 shows the fuzzy values $S, R$, and $Q$.

Step 6. Proposing a compromise solution

In this step, a decision is made based on the values $R, S$, and $Q$ for the alternatives sorted in descending order. Two conditions need to be made a decision, and a set of compromise solutions can be proposed following these two conditions.

Condition 1. Acceptable advantage: $Q\left(A^{(2)}\right)-Q\left(A^{(1)}\right) \geq$ $1 /(m-1)$ where $A^{(1)}$ is the alternative with the first position and $A^{(2)}$ is the alternative with the second position in the ranking list by $Q . m$ is a number of alternatives.
Fig. 2 Weight and ranking of Socio-Economic Development Policies (A1)

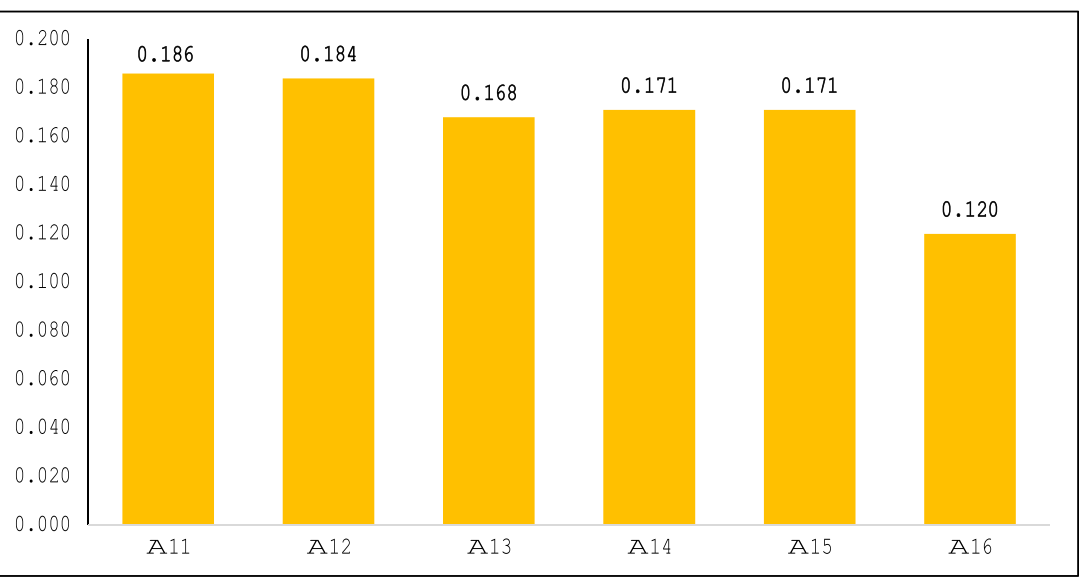


Fig. 3 Weight and ranking of Green Growth Agenda (B2)

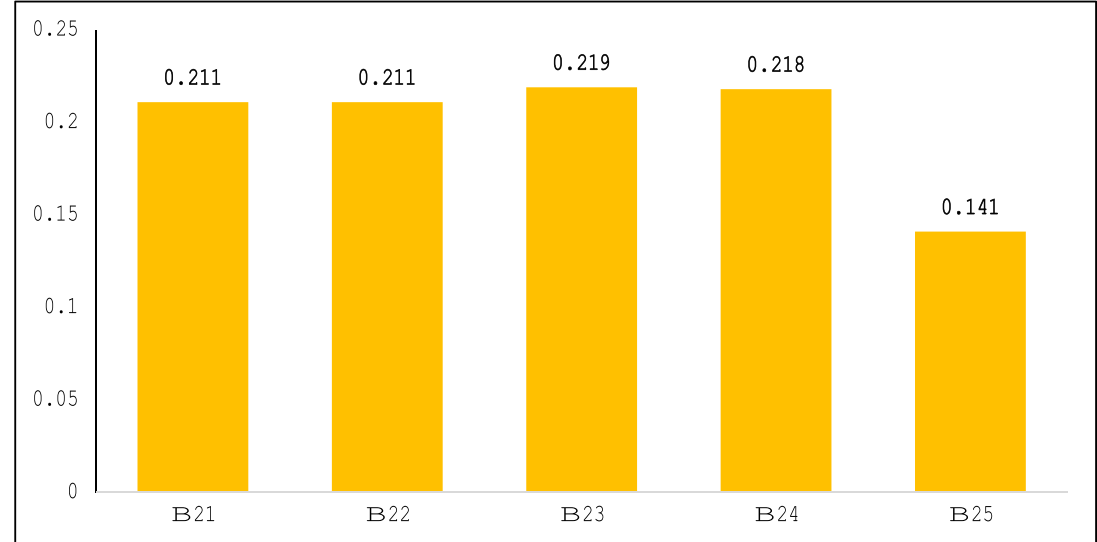

Condition 2. Acceptable stability in decision-making: The alternative $A^{(1)}$ must also be the best ranked by $\mathrm{S}$ or/and R.

If one of the conditions is not satisfied, then a set of compromise solutions is proposed, which consists of the following:

Solution 1. Alternatives $A^{(1)}, A^{(2)}, \ldots, A^{(M)}$ if Condition 1 is not satisfied; Alternative $A^{(M)}$ is determined by $Q\left(A^{(M)}\right)-Q\left(A^{(1)}\right)<1 /(m-1)$ for maximum $M$ (the positions of these alternatives are "in closeness").

Solution 2. Alternatives $A^{(1)}$ and $A^{(2)}$ if only condition 2 is not satisfied.

Solution 3. The alternative with the minimum $Q$ value will be selected as the best Alternative if both conditions are satisfied.

\section{Experts for Fuzzy AHP and Fuzzy VIKOR approach}

It is one of the tough jobs to assess the GEE criteria. The weights assigned by inexperienced individuals are always unimportant and useless in making decisions (Solangi et al. 2019c). Therefore, this research consulted with six professional and experienced experts to assign weights of GEE criteria, sub-criteria, and alternative strategies using Fuzzy AHP and Fuzzy VIKOR methods. These experts belong to academia, research institute, economist, and ecologist. All the responses of experts were gathered by webmail service to analyze the obtained data using Fuzzy AHP method and Fuzzy VIKOR methodologies. Thus, the findings of this research would help in identifying the most suitable GEE criteria, sub-criteria, and strategy in the context of China.

\section{Results and discussion}

In this section, the findings of $10 \mathrm{GEE}$ criteria, 48 sub-criteria, and 5 strategies have been analyzed and ranked using Fuzzy AHP and Fuzzy VIKOR approaches. The GEE criteria and sub-criteria have been evaluated using the Fuzzy AHP method, whereas the Fuzzy VIKOR approach has been used to analyze the GEE strategies. These assessed GEE criteria and strategies are considered to be very crucial for the development and implementation of environmental regulation and GEE in the country. Therefore, the detailed findings are provided in the below sub-sections.
Fig. 4 Weight and ranking of Green Industrial Development (C3)

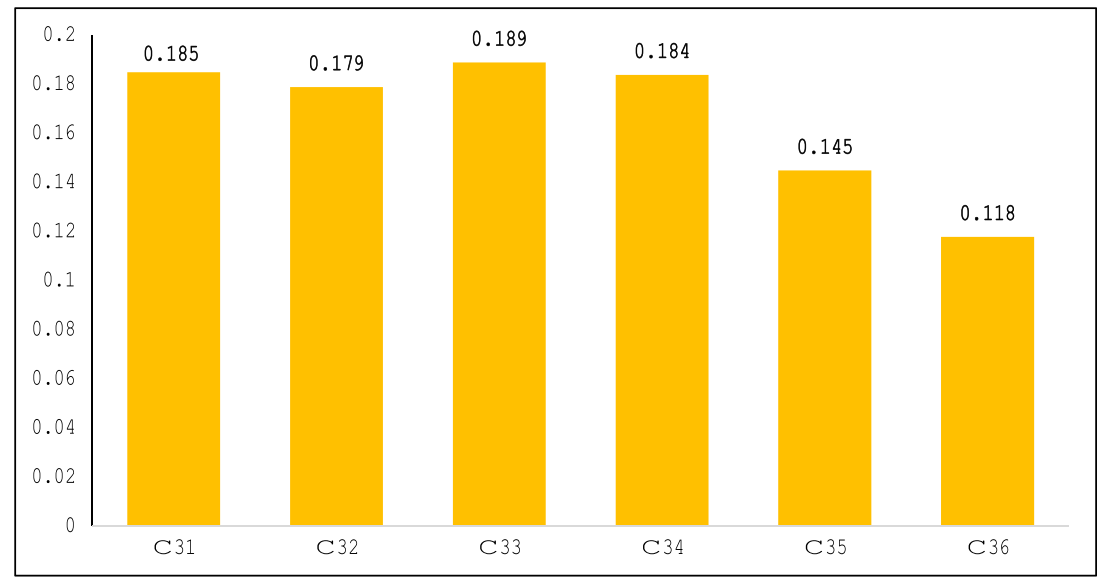


Fig. 5 Weight and ranking of Environmental Regulations (D4)

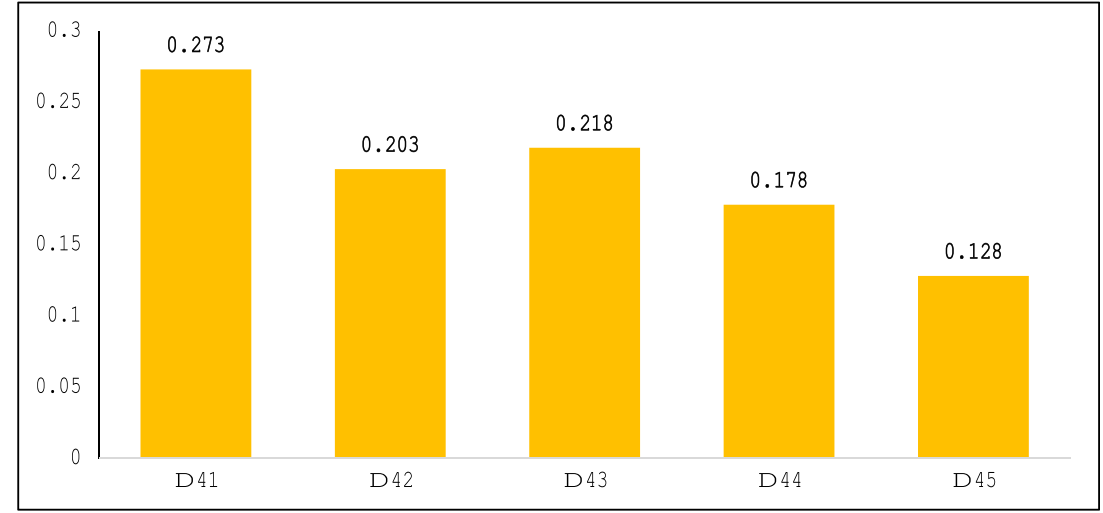

\section{The results of GEE criteria}

This section determines 10 GEE criteria using the Fuzzy AHP method. Table 7 provides the final prioritizing order of GEE criteria. It can be seen that the Socio-Economic Development Policies (A1) is the most relevant GEE criteria with a weight of $0.161(16.10 \%)$ to achieve sustainable environmental regulation and economic efficiency goals. The Green Industrial Development (C3) obtained the second highest weight of 0.124 (12.40\%). The Green Growth Agenda (B2) received third importance with a weight of $0.120(12 \%)$ from the overall 10 GEE criteria. The Blue-Green Infrastructure Development (H8), Pollution Control and Waste Management (I9), and Labor Policies (J10) are considered to be the least significant GEE criteria. Overall, the results present that all these criteria are vital for adopting sustainable environmental regulation and GEE criteria in China. The fuzzy pairwise comparison matrix of the AHP method for GEE criteria and sub-criteria are provided in Appendix 1 Tables 11, 12, 13, 14, 15, 16, 17, 18, 19, 20, 21.

\section{The results of GEE sub-criteria}

In the above section, the GEE criteria were analyzed and ranked using the Fuzzy AHP method. So, in this section, it further obtained the GEE sub-criteria ranking based on each criterion. Figure 2 shows the final prioritizing order of GEE sub-criteria with respect to Socio-Economic Development Policies (A1). According to the findings, the Sustainable Development Initiative (A11) is the priority GEE sub-criteria with a weight of $0.186(18.60 \%)$. The Green Civil Society Initiative(s) (A12) is a second significant GEE sub-criteria with a weight of $0.184(18.40 \%)$. Furthermore, the Gender Mainstreaming (A14) and Sectoral and Regional Development Initiatives (A15) are recognized as the third important GEE sub-criterion with the same weight of 0.171 (17.10\%). Ensuring Stakeholder Participation (A13) and Social Inclusion in Green Economy (A16) has obtained the lowest weight of $0.168(16.80 \%)$ and 0.120 (12\%). The analysis reveals that all these sub-criteria are very important for developing environmental regulation and GEE in China.

Figure 3 shows the weight and ranking of GEE sub-criteria with respect to the Green Growth Agenda (B2). It can be seen that the Simulate Green Investment (B23) is the significant GEE sub-criteria with a weight of $0.219(21.90 \%)$. The Government Investment Incentives (B24) is the subsequent vital GEE sub-criteria with a weight of $0.218(21.80 \%)$. The Inclusive and Collaborative Planning (B21) and Promote Green Growth Patterns (B22) are the third significant GEE sub-criteria with an equal weight of $0.211(21.10 \%)$, respectively. The Sustainable Special Economic Zone Development (B25) obtained the lowest weight of $0.141(14.10 \%)$. It is
Fig. 6 Weight and ranking of Resource Efficiency (E5)

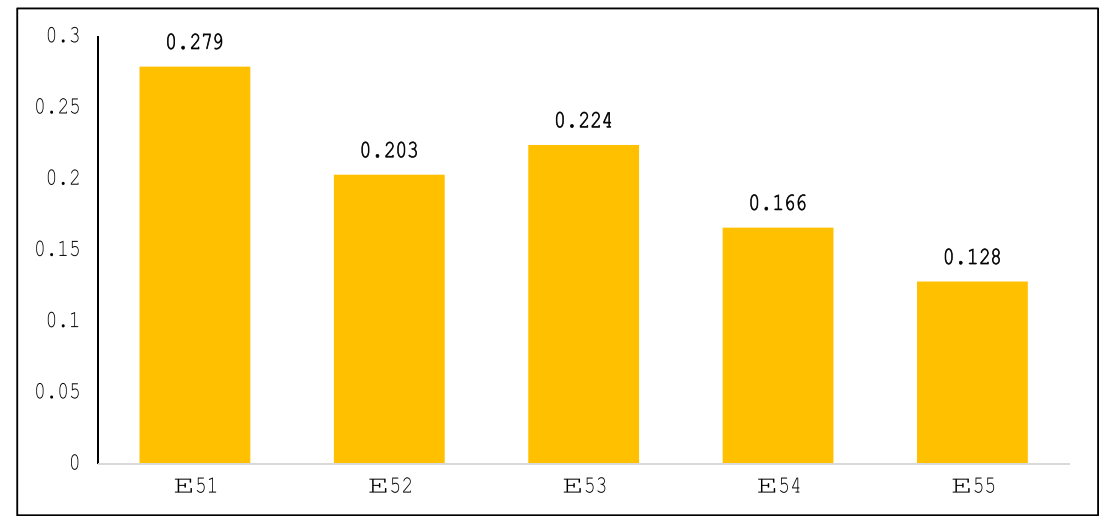


Fig. 7 Weight and ranking of Technological Initiatives and Innovation (F6)

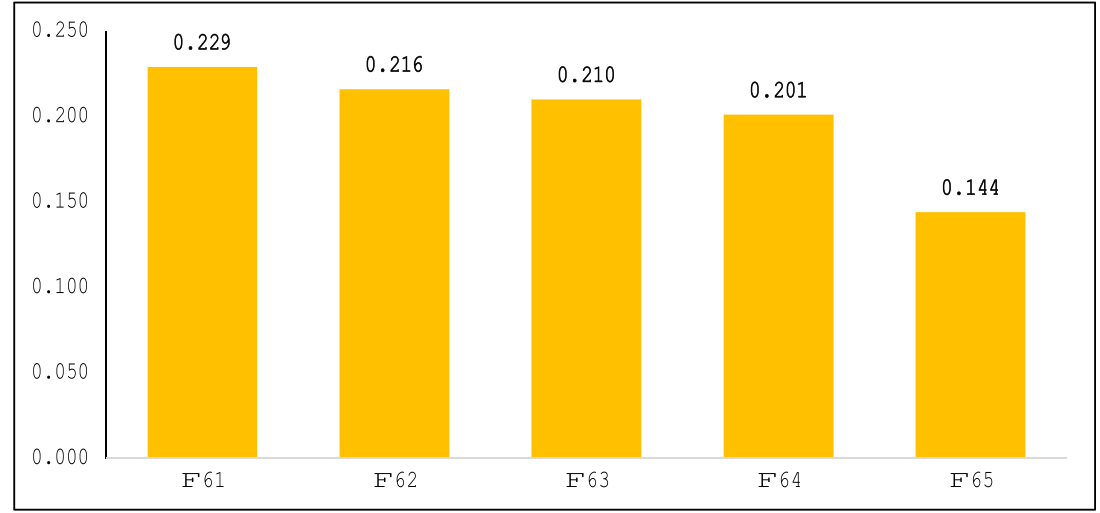

identified that all these 5 GEE sub-criteria are vital under the B2 category.

Figure 4 shows the weight and ranking of GEE sub-criteria under Green Industrial Development (C3). Under this category, the Green Innovation Initiative for Green Industrial Growth (C33) ranked the first crucial GEE sub-criteria with a weight of 0.189 (18.90\%). The Green Product Innovation (C31) obtained the second highest importance with a weight of $0.185(18.50 \%)$. The Industrial Specialization (C34) received third vital GEE sub-criteria with a weight of 0.184 (18.40\%). The green Craft Innovation (C32), Industrial Diversity (C35), and Industrial Competition (C36) are moderate to least important sub-criterion to attain the environmental regulation and GEE alternative strategies.

Figure 5 shows the weight and ranking of GEE sub-criteria under Environmental Regulations (D4). Under this sub-criterion, the ranking indicates that the Administrative Environmental Regulations (D41) received the highest weight of 0.273 (27.30\%). The Monitoring and Evaluation System Development (D43) obtained the second highest weight of $0.218(21.80 \%)$. The Market-based Environmental Regulations (D42) got third important GEE sub-criteria with a weight of 0.203 (20.30\%). Public Participation in Environmental Regulation and Compliance (D44) and Land/Planning laws (D45) achieved the lowest weight scores under the D4 category.
It is imperative to mention that the analyzed GEE sub-criterion is very significant to implement sustainable environmental regulation and the GEE system in the country.

Figure 6 presents the weight and ranking of the GEE subcriterion with respect to Resource Efficiency (E5). It shows that the Minimization of Environmental Risk (E51) obtained the first ranked GEE sub-criteria under the E5 category with a weight of 0.279 (27.90\%). Reducing Waste through Industrial Symbiosis (E53) achieved the second highest weight of 0.224 (22.40\%). The Sustainable Public Procurement (E52), Reduce Resources and Energy Consumption (E54), and Efficient Land Use (E55) obtained the third, fourth, and fifth ranks, respectively.

Figure 7 displays the weight and ranking of the GEE subcriterion under Technological Initiatives and Innovation (F6). The Direct Government Funding and Tax Incentives (F61) were reported as the highest ranked GEE sub-criteria with a weight of 0.229 (22.90\%). The Intellectual Property Laws (F62) achieved the second highest weight of 0.216 (21.60\%). Research and Development (R\&D) (F63) is considered to be the third important GEE sub-criteria with a weight of 0.210 (21\%). The Green Technology Innovation (F64) and Marketization Innovation (F65) were reported to be the least vital GEE sub-criterion with a weight of $0.201(20.10 \%)$ and $0.144(14.40 \%)$.
Fig. 8 Weight and ranking of Green Energy Production and Consumption Practices (G7)

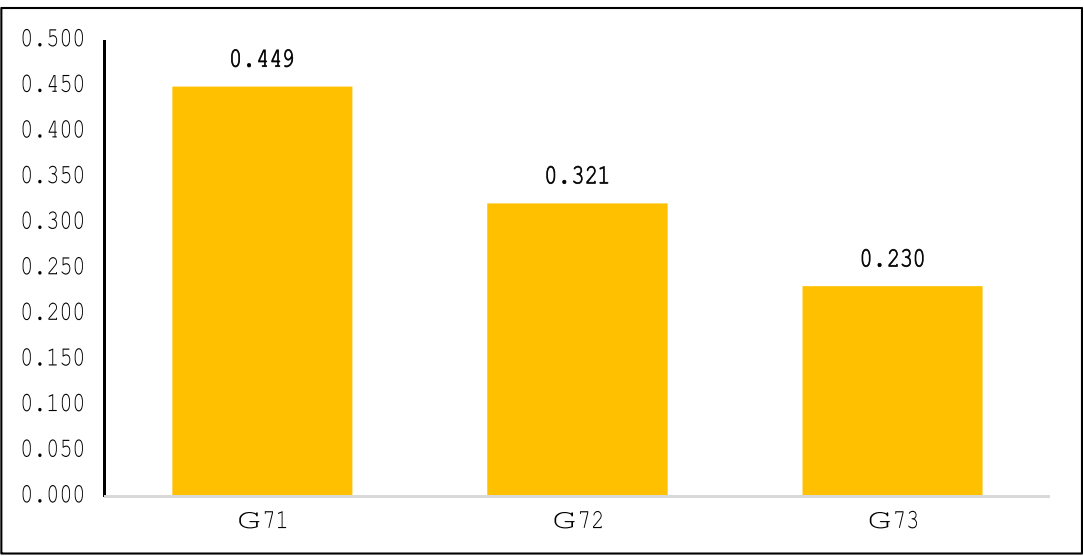


Fig. 9 Weight and ranking of Blue-Green Infrastructure Development (H8)

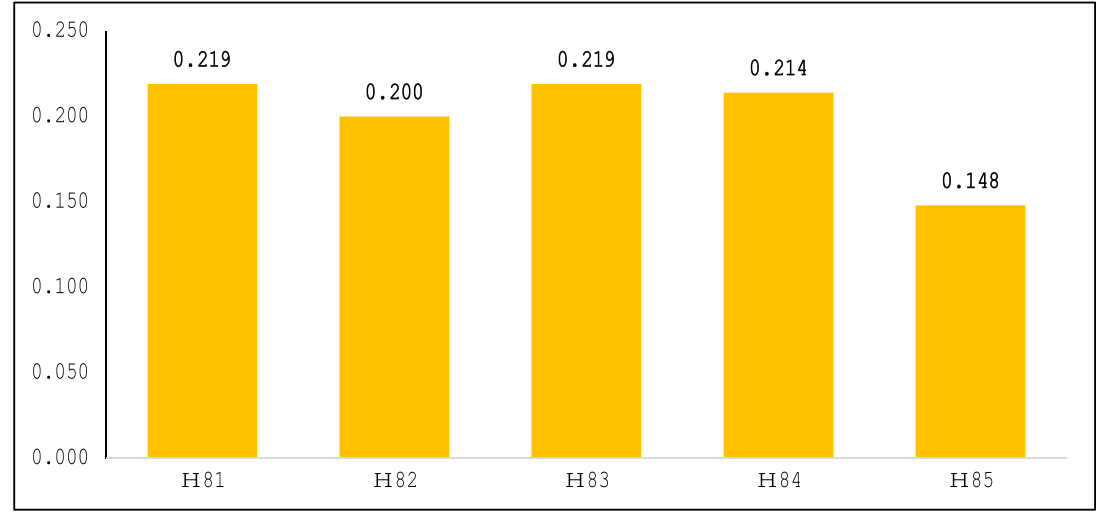

Figure 8 displays the weight and ranking of GEE subcriteria with respect to Green Energy Production and Consumption Practices (G7). The analysis reveals that the Green Energy Initiative (G71) received the highest weight of 0.449 (44.90\%), followed by Energy-Saving Technology Adoption (G72) and Green Energy Transmission and Distribution System (G73) with a weight of 0.321 (32.10\%) and $0.230(23 \%)$.

Figure 9 depicts the weight and ranking of GEE sub-criteria under Blue-Green Infrastructure Development (H8). The findings show that the Blue Infrastructure Development (H81) and Recycling Infrastructure (H83) attained the priority order with an equal weight of 0.219 (21.90\%). The Transport Infrastructure (H84) is considered the second vital GEE subcriteria with a weight of $0.214(21.40 \%)$. The Green Stormwater Management System Development (H82) was the third crucial GEE sub-criteria with a weight of 0.200 $(20 \%)$. The Green Buildings (H85) is considered the least vital sub-criteria with a weight of $0.148(14.80 \%)$.

Figure 10 presents the weight and ranking of GEE subcriteria with respect to the Pollution Control and Waste Management (I9). The results recommend that the Air Pollution Control (I91) is the most significant GEE subcriteria with a weight of $0.300(30 \%)$. Wastewater Management (192) appeared as the second vital sub-criteria with a weight of $0.264(26.40 \%)$. The Shared and Circular
Economy Promotion (194) and Solid Waste Management (I93) recognized as third and fourth vital GEE cub-criterion with a weight of $0.247(24.70 \%)$ and 0.188 (18.80\%).

Figure 11 shows the weight and ranking of GEE subcriteria under Labor Policies (J10). The results indicate that Skill Development (J101) is the top-ranked GEE sub-criteria with a weight of $0.277(27.70 \%)$. The SME Development (J103) appeared as the second important sub-criteria with a weight of $0.254(25.40 \%)$. The Green Jobs (J104) and Occupational Safety and Health (J102) have been identified as third and fourth vital GEE sub-criterion with a weight of $0.242(24.20 \%)$ and $0.228(22.80 \%)$. Therefore, it is determined that most of the sub-criteria under the J10 category are very significant for achieving sustainable environmental regulation and GEE goals in the country.

\section{Results of overall GEE sub-criteria}

This sub-section finally determines the overall ranking of GEE sub-criteria with respect to the decision-making goal of the study. The overall weight of sub-criteria has been obtained through multiplying the initial weights of sub-criteria to their respective GEE criteria. Table 8 shows the overall weight and ranking of GEE sub-criteria. The findings reveal that Green Energy Initiative (G71) and Energy-Saving Technology Adoption (G72) are the most significant sub-criteria among
Fig. 10 Weight and ranking of Pollution Control and Waste Management (I9)

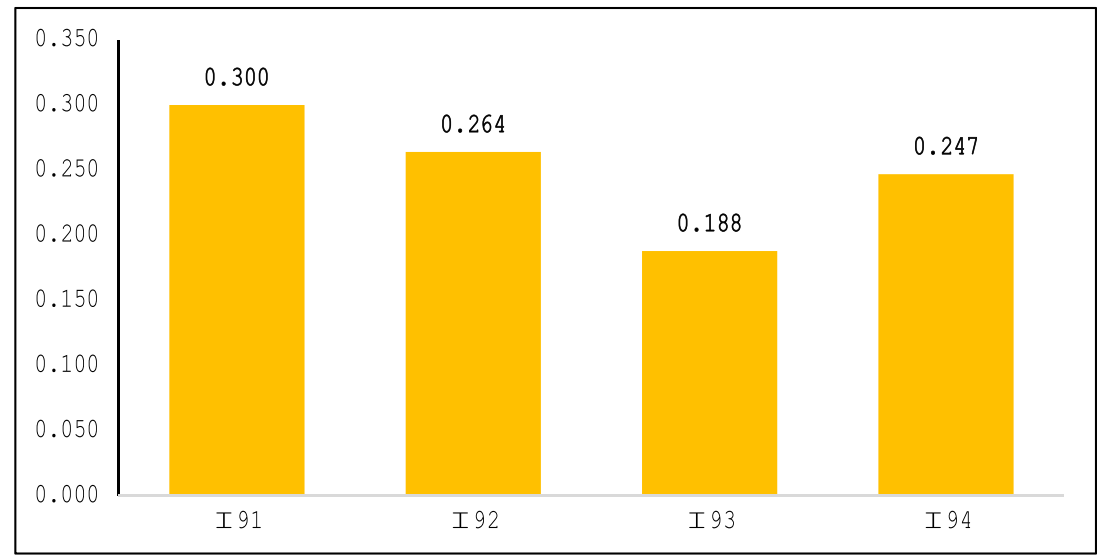


Fig. 11 Weight and ranking of Labor Policies (J10)

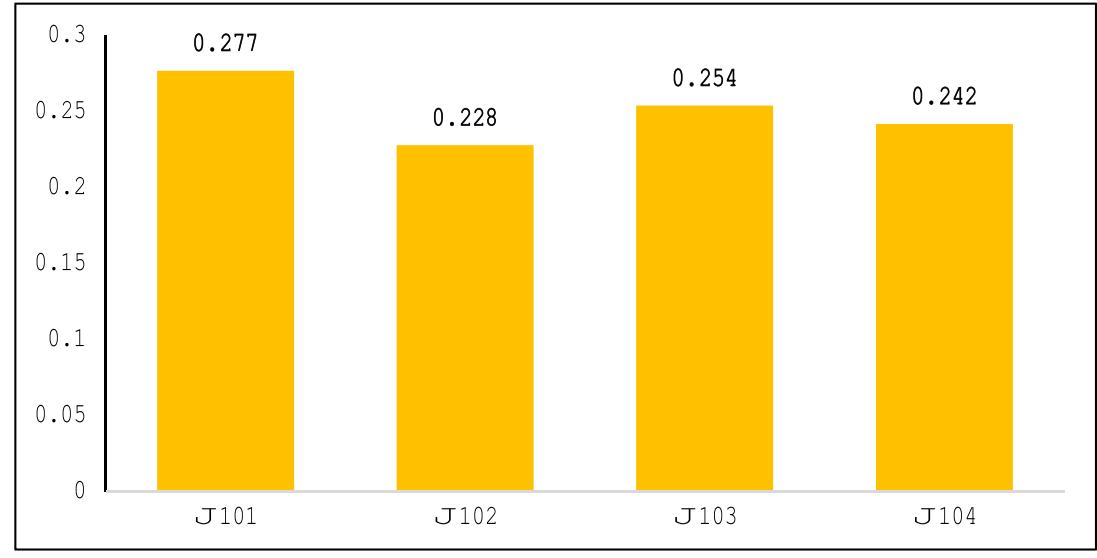

all 48 GEE sub-criteria. The G71 and G72 sub-criteria reported the highest final weights of $0.0507(5.07 \%)$ and 0.0362 $(3.62 \%)$. These GEE sub-criteria belong to the Green Energy Production and Consumption Practices (G7). The Sustainable Development Initiative (A11) followed by Green Civil Society Initiative(s) (A12), Gender Mainstreaming (A14), and Sectoral and Regional Development Initiatives (A15) are the next vital GEE subcriterion. These sub-criteria A11, A12, A14, and A15 belong to the Socio-Economic Development Policies (A1) category. The remaining GEE sub-criteria have been prioritized as follows: $\mathrm{A} 13<\mathrm{B} 23<\mathrm{B} 24<\mathrm{J} 101<\mathrm{G} 73<\mathrm{B} 21<\mathrm{B} 22<\mathrm{J} 103<$ $\mathrm{C} 33<\mathrm{H} 81<\mathrm{C} 31<\mathrm{C} 34<\mathrm{I} 91<\mathrm{J} 104<\mathrm{H} 84<\mathrm{C} 32<\mathrm{J} 102<$ $\mathrm{H} 82<\mathrm{I} 92<\mathrm{F} 61<\mathrm{A} 16<\mathrm{I} 94<\mathrm{F} 62<\mathrm{D} 41<\mathrm{F} 63<\mathrm{C} 35<\mathrm{F} 64$ $<$ B $25<$ H $85<$ C $36<$ D $43<$ E $51<$ I $93<$ D $42<$ F $65<$ D $44<$ $\mathrm{E} 53<\mathrm{E} 52<\mathrm{E} 54<\mathrm{D} 45<\mathrm{E} 55$. Finally, the findings show that all GE sub-criteria are suitable to be applied for the achievement of sustainable environmental regulation and GEE system in China.

\section{Results of Fuzzy VIKOR (GEE alternative strategies)}

In this section, the ranking of $5 \mathrm{GE}$ alternative strategies has been evaluated using the Fuzzy VIKOR methodology. A group analyzed 6 experts to form group decision-making at the end. The fuzzy decision matrix, fuzzy positive and negative ideal values, fuzzy normalized decision matrix, and the fuzzy values $S, R$, and $Q$ are presented in Appendix 2 of this paper. All criteria of this study were considered as benefit criteria.

In the adoption of the Fuzzy VIKOR approach, the strategy with lowest $Q$ value has been considered as an optimal alternative. The obtained fuzzy values of $S, R$, and $Q$ are presented in Table 9. Moreover, the final ranking based on the $Q$ value is shown in Table 10. The findings of the Fuzzy VIKOR method indicate that resource efficiency and green purchasing strategy (S2) is the most suitable alternative for sustainable development in China. Local production and utilization strategy (S3) is the second important alternative to follow sustainable environmental regulation and GEE in China. The green economic development strategy (S1) is considered as a third vital alternative of the study. The waste stream management strategy (S4) and green infrastructure strategy (S5) are the least significant alternatives. It is identified that all these strategies are very crucial for the sustainable economic, social, and environmental development of the country.

The Fuzzy AHP and Fuzzy VIKOR methods have been applied systematically to determine the environmental regulation and GEE criteria problem in the context of Chinese economy. This process will serve the country to achieve green development phase. Moreover, this research will help the government and decision-makers to select and evaluate the feasible GEE criteria and alternative strategies for the sustainable development of the country.

\section{Discussion}

This research aims to select, assess, and rank the essential GEE criteria, sub-criteria, and alternative strategies for the implementation of sustainable economic, social, and environmental development in China. This decision-making problem comprehensively provides the comprehension to accomplish environmental regulation and GEE in the post-COVID-19 situation. This process has been done using a fuzzy-based multicriteria analysis. In this regard, the fuzzy-based AHP and VIKOR methods have been used to analyze and rank the GEE criteria and alternative strategies. The evaluation process in the real-life example is complicated and uncertain. Thus, this research used the fuzzy set theory to reduce uncertainty, shortcoming, and fuzziness during the decision-making process.

The ranking of GEE criteria and sub-criteria are presented in Figs. 2, 3, 4, 5, 6, 7, 8, 9, and 10. The global weights of subcriteria are shown in Table 8. Among 10 GEE criteria, SocioEconomic Development Policies (A1), Green Industrial 
Table 8 The overall weight and ranking of GEE sub-criteria with respect to the decision goal of the study

\begin{tabular}{|c|c|c|c|}
\hline Code & GEE sub-criteria & Weight & Rank \\
\hline A11 & Sustainable Development Initiative & 0.0299 & 3 \\
\hline A12 & Green Civil Society Initiative(s) & 0.0296 & 4 \\
\hline A13 & Ensuring Stakeholder Participation & 0.0270 & 6 \\
\hline A14 & Gender Mainstreaming & 0.0275 & 5 \\
\hline A 15 & Sectoral and Regional Development Initiatives & 0.0275 & 5 \\
\hline A16 & Social Inclusion in Green Economy & 0.0193 & 25 \\
\hline B21 & Inclusive and Collaborative Planning & 0.0253 & 11 \\
\hline B22 & Promote Green Growth Patterns & 0.0253 & 11 \\
\hline $\mathrm{B} 23$ & Simulate Green Investment & 0.0262 & 7 \\
\hline B24 & Government Investment Incentives (GIIs) & 0.0261 & 8 \\
\hline B25 & Sustainable Special Economic Zone Development & 0.0169 & 32 \\
\hline $\mathrm{C} 31$ & Green Product Innovation (GPI) & 0.0229 & 15 \\
\hline $\mathrm{C} 32$ & Green Craft Innovation (GCI) & 0.0221 & 20 \\
\hline $\mathrm{C} 33$ & Green Innovation Initiative (GII) for Green Industrial Growth (GIG) & 0.0234 & 13 \\
\hline $\mathrm{C} 34$ & Industrial Specialization & 0.0228 & 16 \\
\hline $\mathrm{C} 35$ & Industrial Diversity & 0.0179 & 30 \\
\hline $\mathrm{C} 36$ & Industrial Competition & 0.0146 & 34 \\
\hline D41 & Administrative Environmental Regulations (AERs) & 0.0182 & 28 \\
\hline D42 & Market-based Environmental Regulations (MERs) & 0.0136 & 38 \\
\hline D43 & Monitoring and Evaluation System Development & 0.0146 & 35 \\
\hline D44 & Public Participation in Environmental Regulation and Compliance & 0.0119 & 40 \\
\hline D45 & Land/Planning Laws & 0.0085 & 44 \\
\hline E51 & Minimization of Environmental Risk & 0.0145 & 36 \\
\hline E52 & Sustainable Public Procurement & 0.0105 & 42 \\
\hline E53 & Reducing Waste through Industrial Symbiosis & 0.0116 & 41 \\
\hline E54 & Reduce Resources and Energy Consumption & 0.0086 & 43 \\
\hline E55 & Efficient Land Use & 0.0066 & 45 \\
\hline F61 & Direct Government Funding and Tax Incentives & 0.0196 & 24 \\
\hline F62 & Intellectual Property Laws & 0.0185 & 27 \\
\hline F63 & Research and Development (R\&D) & 0.0180 & 29 \\
\hline F64 & Green Technology Innovation & 0.0172 & 31 \\
\hline F65 & Marketization Innovation & 0.0123 & 39 \\
\hline G71 & Green Energy Initiative & 0.0507 & 1 \\
\hline G72 & Energy-Saving Technology Adoption & 0.0362 & 2 \\
\hline G73 & Green Energy Transmission and Distribution System & 0.0259 & 10 \\
\hline H81 & Blue Infrastructure Development & 0.0232 & 14 \\
\hline H82 & Green Storm water Management System Development & 0.0212 & 22 \\
\hline H83 & Recycling Infrastructure & 0.0232 & 14 \\
\hline H84 & Transport Infrastructure & 0.0226 & 19 \\
\hline H85 & Green Buildings & 0.0156 & 33 \\
\hline I91 & Air Pollution Control & 0.0228 & 17 \\
\hline $\mathrm{I} 92$ & Wastewater Management & 0.0200 & 23 \\
\hline $\mathrm{I} 93$ & Solid Waste Management & 0.0142 & 37 \\
\hline I94 & Shared and Circular Economy Promotion & 0.0187 & 26 \\
\hline J101 & Skill Development & 0.0260 & 9 \\
\hline $\mathrm{J} 102$ & Occupational Safety and Health (OSH) & 0.0214 & 21 \\
\hline J103 & SME Development & 0.0238 & 12 \\
\hline J104 & Green Jobs & 0.0227 & 18 \\
\hline
\end{tabular}


Table 9 Crisp values and ranking of alternatives based on $S, R$, and $Q$

\begin{tabular}{lllllll}
\hline & Crisp value of $R$ & Rank in $R$ & Crisp value of $S$ & Rank in $S$ & Crisp value of $Q$ & Rank in $Q$ \\
\hline S1 & 0.01 & 4 & 0.155 & 3 & 0.085 & 3 \\
S2 & 0.006 & 1 & 0.093 & 1 & 0.001 & 1 \\
S3 & 0.007 & 2 & 0.124 & 2 & 0.034 & 2 \\
S4 & 0.009 & 3 & 0.204 & 4 & 0.091 & 4 \\
S5 & 0.011 & 5 & 0.216 & 5 & 0.114 & 5 \\
\hline
\end{tabular}

Development (C3), and Green Growth Agenda (B2) are the most important criteria for the adoption and boosting up of the sustainable environmental regulation and GEE in China. Furthermore, the final ranking of sub-criteria shows that Green Energy (G71), Energy-Saving Technology Adoption (G72), and Sustainable Development Initiative (A11) are the most significant criteria. After obtaining the findings of criteria and sub-criteria using the Fuzzy AHP approach, this research uses the Fuzzy VIKOR method to analyze and rank the various strategies. This method indicates that resource efficiency and green purchasing (S2) is the most suitable strategy for developing environmental regulation and GEE in the country. The local production and utilization (S3) and green economic development (S1) are the second and third vital GEE alternative strategies.

There are various previous researches on the transformation of environmental regulation and GEE. Such as transition to green industrial growth (Feng and Chen 2018), environmental regulation can decrease the harmful influence of green technological innovation (Liu et al. 2020), and environmental regulation, industrial innovation, and green development in the context Chinese manufacturing (Yuan and Xiang 2018). Furthermore, the economic growth, and energy regulation, and environmental degradation for OECD countries (Lorente and Álvarez-Herranz 2016). However, this research is the very first attempt in the context of China. Moreover, none of the authors has used fuzzy-based multi-criteria analysis to solve this multi-faceted decision-making problem. This study uses Fuzzy AHP and Fuzzy VIKOR methods to determine this decision-making problem. This research is unique in terms of identifying, evaluating, and ranking environmental regulation and GEE criteria, sub-criteria, and strategies. The proposed research framework determined the 10 criteria, 48 sub-criteria, and 5 strategies. To the best of the author's knowledge, none of the studies utilized composed these important criteria for the evaluation process. The proposed fuzzy multi-criteria analysis framework of this research is a very supportive tool for the government, decision-makers, and stakeholders for sustainable economic and environmental development.

\section{Conclusion}

The transition to a green economy and the achievement of GEE are the objectives of governments all over the globe. Achievement of GEE in an economy may depend on specifics of an economy's development, patterns of development, the structure of the economy, structure of environmental regulations, and their implementation in the economy. Moreover, the COVID-19 outbreak diverted the consideration of the governments toward an unparalleled worldwide health crisis posed by a novel coronavirus. The Chinese economy is the first country, which is hit by the COVID-19 pandemic, focusing on economic retrieval. In addition to this, multiple sociocultural-economic-environmental-institutional factors may have their insinuations of the eco-efficient and GEE of the economy. Like other economies, the Chinese economy has started focusing on green economic development and GEE to achieve SDGs. The present study is a pioneer attempt to examine and prioritize GEE alternative strategies in the context of environmental regulations. This study is a fuzzy-based multi-criteria decision analysis in the context of environmental regulations and GEE in China. This study assesses and
Table 10 Final alternatives (strategies) ranking according to the lowest $Q$ values

\begin{tabular}{llll}
\hline Code & Strategy & Crisp value of $Q$ & Rank final \\
\hline S1 & Green economic development & 0.085 & 3 \\
S2 & Resource efficiency and green purchasing & 0.001 & 1 \\
S3 & Local production and utilization & 0.034 & 2 \\
S4 & Waste stream management & 0.091 & 4 \\
S5 & Green infrastructure & 0.114 & 5 \\
\hline
\end{tabular}


prioritizes 5 alternative strategies for GEE in China while identifying 10 criteria and their respective sub-criteria.

The mostly used multi-criteria tool of Fuzzy AHP has been employed to assess and prioritize the criteria and sub-criteria. The Fuzzy VIKOR has been used to evaluate and rank the 5 alternative GEE strategies. The developed criteria, subcriteria, and strategies are qualitative; therefore, it is difficult to analyze and obtain accurate results. Thus, fuzzy-based multi-criteria analysis has been utilized to analyze this decision-making problem. The Fuzzy AHP and Fuzzy VIKOR methods allow an expert to use quantitative terms using a TFN scale. The TFNs can help deal with uncertain and subjective data for reducing ambiguity and uncertainty during the evaluation process. The empirical results of Fuzzy AHP show that Socio-Economic Development
Policies (A1) are the most vital criteria to initiate green economic development and GEE for the achievement of SDGs in China. The final ranking of sub-criteria shows that Green Energy (G71) is the most significant in overall sub-criteria. The Fuzzy VIKOR approach shows that resource efficiency and green purchasing (S2) is the most crucial strategy in transiting to the green economy in China. It is determined that the proposed fuzzy decision analysis framework is critical in adopting GEE criteria and strategies in the context of China. Therefore, the governments and decision-makers can apply this model to assess and rank the GEE criteria and alternative strategies for sustainable economic, environmental, and social development in the post-COVID-19 scenario.

\section{Appendix 1. The Fuzzy AHP results}

Table 11 Fuzzy pairwise comparison with respect to the decision-making goal of the study

\begin{tabular}{|c|c|c|c|c|c|c|c|c|c|c|}
\hline & A1 & B2 & C3 & D4 & E5 & F6 & G7 & H8 & I9 & $\mathrm{J} 10$ \\
\hline $\mathrm{A} 1$ & $\begin{array}{c}(1.000,1.000 \\
1.000)\end{array}$ & $\begin{array}{c}(1.000,1.944 \\
4.000)\end{array}$ & $\begin{array}{c}(1.000,2.038 \\
4.000)\end{array}$ & $\begin{array}{c}(1.000,2.181 \\
4.000)\end{array}$ & $\begin{array}{c}(1.000,2.883 \\
5.000)\end{array}$ & $\begin{array}{c}(1.000,2.797 \\
6.000)\end{array}$ & $\begin{array}{c}(1.000,2.696 \\
5.000)\end{array}$ & $\begin{array}{c}(2.000,3.268 \\
6.000)\end{array}$ & $\begin{array}{c}(1.000,3.358 \\
6.000)\end{array}$ & $\begin{array}{c}(2.000,3.597 \\
6.000)\end{array}$ \\
\hline B2 & $\begin{array}{c}(0.250,0.514 \\
1.000)\end{array}$ & $\begin{array}{c}(1.000,1.000 \\
1.000)\end{array}$ & $\begin{array}{c}(1.000,1.000 \\
1.000)\end{array}$ & $\begin{array}{c}(1.000,1.122 \\
3.000)\end{array}$ & $\begin{array}{c}(1.000,1.347 \\
4.000)\end{array}$ & $\begin{array}{c}(1.000,1.998 \\
3.000)\end{array}$ & $\begin{array}{c}(1.000,1.413 \\
3.000)\end{array}$ & $\begin{array}{c}(1.000,1.905 \\
4.000)\end{array}$ & $\begin{array}{c}(1.000,1.347 \\
4.000)\end{array}$ & $\begin{array}{c}(1.000,1.259 \\
3.000)\end{array}$ \\
\hline C3 & $\begin{array}{c}(0.250,0.491 \\
1.000)\end{array}$ & $\begin{array}{c}(1.000,1.000 \\
1.000)\end{array}$ & $\begin{array}{c}(1.000,1.000 \\
1.000)\end{array}$ & $\begin{array}{c}(1.000,1.122 \\
3.000)\end{array}$ & $\begin{array}{c}(1.000,1.780 \\
3.000)\end{array}$ & $\begin{array}{c}(1.000,1.586 \\
3.000)\end{array}$ & $\begin{array}{c}(1.000,1.619 \\
4.000)\end{array}$ & $\begin{array}{c}(1.000,1.697 \\
4.000)\end{array}$ & $\begin{array}{c}(1.000,1.512 \\
4.000)\end{array}$ & $\begin{array}{c}(1.000,2.181 \\
4.000)\end{array}$ \\
\hline D4 & $\begin{array}{c}(0.250,0.459 \\
1.000)\end{array}$ & $\begin{array}{c}(0.333,0.891 \\
1.000)\end{array}$ & $\begin{array}{c}(0.333,0.891 \\
1.000)\end{array}$ & $\begin{array}{c}(1.000,1.000 \\
1.000)\end{array}$ & $\begin{array}{c}(1.000,1.000 \\
1.000)\end{array}$ & $\begin{array}{c}(1.000,2.038 \\
4.000)\end{array}$ & $\begin{array}{c}(1.000,1.259 \\
3.000)\end{array}$ & $\begin{array}{c}(1.000,1.259 \\
3.000)\end{array}$ & $\begin{array}{c}(1.000,1.905 \\
4.000)\end{array}$ & $\begin{array}{c}(1.000,1.697, \\
4.000)\end{array}$ \\
\hline E5 & $\begin{array}{c}(0.200,0.347 \\
1.000)\end{array}$ & $\begin{array}{c}(0.250,0.742 \\
1.000)\end{array}$ & $\begin{array}{c}(0.333,0.562 \\
1.000)\end{array}$ & $\begin{array}{c}(1.000,1.000 \\
1.000)\end{array}$ & $\begin{array}{c}(1.000,1.000 \\
1.000)\end{array}$ & $\begin{array}{c}(1.000,1.259 \\
3.000)\end{array}$ & $\begin{array}{c}(1.000,1.586 \\
3.000)\end{array}$ & $\begin{array}{c}(1.000,1.259 \\
3.000)\end{array}$ & $\begin{array}{c}(1.000,1.586, \\
3.000)\end{array}$ & $\begin{array}{c}(1.000,1.905, \\
4.000)\end{array}$ \\
\hline F6 & $\begin{array}{c}(0.167,0.358 \\
1.000)\end{array}$ & $\begin{array}{c}(0.333,0.501 \\
1.000)\end{array}$ & $\begin{array}{c}(0.333,0.631 \\
1.000)\end{array}$ & $\begin{array}{c}(0.250,0.491 \\
1.000)\end{array}$ & $\begin{array}{c}(0.333,0.794 \\
1.000)\end{array}$ & $\begin{array}{c}(1.000,1.000 \\
1.000)\end{array}$ & $\begin{array}{c}(1.000,1.122 \\
3.000)\end{array}$ & $\begin{array}{c}(1.000,1.586 \\
3.000)\end{array}$ & $\begin{array}{c}(1.000,1.413, \\
3.000)\end{array}$ & $\begin{array}{c}(1.000,1.413 \\
3.000)\end{array}$ \\
\hline G7 & $\begin{array}{c}(0.200,0.371 \\
1.000)\end{array}$ & $\begin{array}{c}(0.333,0.708 \\
1.000)\end{array}$ & $\begin{array}{c}(0.250,0.618 \\
1.000)\end{array}$ & $\begin{array}{c}(0.333,0.794 \\
1.000)\end{array}$ & $\begin{array}{c}(0.333,0.631 \\
1.000)\end{array}$ & $\begin{array}{c}(0.333,0.891 \\
1.000)\end{array}$ & $\begin{array}{c}(1.000,1.000 \\
1.000)\end{array}$ & $\begin{array}{c}(1.000,1.122 \\
3.000)\end{array}$ & $\begin{array}{c}(1.000,1.259 \\
3.000)\end{array}$ & $\begin{array}{c}(1.000,1.259 \\
3.000)\end{array}$ \\
\hline H8 & $\begin{array}{c}(0.167,0.306 \\
0.500)\end{array}$ & $\begin{array}{c}(0.250,0.525 \\
1.000)\end{array}$ & $\begin{array}{c}(0.250,0.589 \\
1.000)\end{array}$ & $\begin{array}{c}(0.333,0.794 \\
1.000)\end{array}$ & $\begin{array}{c}(0.333,0.794 \\
1.000)\end{array}$ & $\begin{array}{c}(0.333,0.631 \\
1.000)\end{array}$ & $\begin{array}{c}(0.333,0.891 \\
1.000)\end{array}$ & $\begin{array}{c}(1.000,1.000 \\
1.000)\end{array}$ & $\begin{array}{c}(1.000,1.259 \\
3.000)\end{array}$ & $\begin{array}{c}(1.000,1.586 \\
3.000)\end{array}$ \\
\hline I9 & $\begin{array}{c}(0.167,0.298 \\
1.000)\end{array}$ & $\begin{array}{c}(0.250,0.742 \\
1.000)\end{array}$ & $\begin{array}{c}(0.250,0.661 \\
1.000)\end{array}$ & $\begin{array}{c}(0.250,0.525 \\
1.000)\end{array}$ & $\begin{array}{c}(0.333,0.631 \\
1.000)\end{array}$ & $\begin{array}{c}(0.333,0.708 \\
1.000)\end{array}$ & $\begin{array}{c}(0.333,0.794 \\
1.000)\end{array}$ & $\begin{array}{c}(0.333,0.794 \\
1.000)\end{array}$ & $\begin{array}{c}(1.000,1.000 \\
1.000)\end{array}$ & $\begin{array}{c}(1.000,1.259, \\
3.000)\end{array}$ \\
\hline $\mathrm{J} 10$ & $\begin{array}{c}(0.167,0.278 \\
0.500)\end{array}$ & $\begin{array}{c}(0.333,0.794 \\
1.000)\end{array}$ & $\begin{array}{c}(0.250,0.459 \\
1.000)\end{array}$ & $\begin{array}{c}(0.250,0.589 \\
1.000)\end{array}$ & $\begin{array}{c}(0.250,0.525 \\
1.000)\end{array}$ & $\begin{array}{c}(0.333,0.708 \\
1.000)\end{array}$ & $\begin{array}{c}(0.333,0.794 \\
1.000)\end{array}$ & $\begin{array}{c}(0.333,0.631 \\
1.000)\end{array}$ & $\begin{array}{c}(0.333,0.794 \\
1.000)\end{array}$ & $\begin{array}{c}(1.000,1.000 \\
1.000)\end{array}$ \\
\hline
\end{tabular}

Table 12 Fuzzy pairwise comparison with respect to Socio-Economic Development Policies (A1)

\begin{tabular}{lllllll}
\hline & A11 & A12 & A13 & A14 & A15 & A16 \\
\hline A11 & $(1.000,1.000,1.000)$ & $(0.333,1.201,4.000)$ & $(1.000,1.619,4.000)$ & $(1.000,1.442,4.000)$ & $(0.333,1.348,4.000)$ & $(1.000,2.492,6.000)$ \\
A12 & $(0.250,0.833,3.003)$ & $(1.000,1.000,1.000)$ & $(1.000,1.618,4.000)$ & $(0.333,1.201,4.000)$ & $(0.333,1.513,5.000)$ & $(1.000,2.288,5.000)$ \\
A13 & $(0.250,0.618,1.000)$ & $(0.250,0.618,1.000)$ & $(1.000,1.000,1.000)$ & $(0.333,1.000,3.000)$ & $(0.250,1.048,3.000)$ & $(1.000,2.182,4.000)$ \\
A14 & $(0.250,0.693,1.000)$ & $(0.250,0.833,3.003)$ & $(0.333,1.000,3.003)$ & $(1.000,1.000,1.000)$ & $(0.250,1.122,4.000)$ & $(1.000,1.816,4.000)$ \\
A15 & $(0.250,0.742,3.003)$ & $(0.200,0.661,3.003)$ & $(0.333,0.954,4.000)$ & $(0.250,0.891,4.000)$ & $(1.000,1.000,1.000)$ & $(1.000,1.512,4.000)$ \\
A16 & $(0.167,0.401,1.000)$ & $(0.200,0.437,1.000)$ & $(0.250,0.458,1.000)$ & $(0.250,0.551,1.000)$ & $(0.250,0.661,1.000)$ & $(1.000,1.000,1.000)$ \\
\hline
\end{tabular}


Table 13 Fuzzy pairwise comparison with respect to Green Growth Agenda (B2)

\begin{tabular}{llllll}
\hline & B21 & B22 & B23 & B24 & B25 \\
\hline B21 & $(1.000,1.000,1.000)$ & $(0.250,0.934,3.000)$ & $(0.250,0.833,4.000)$ & $(0.250,0.890,4.000)$ & $(1.000,2.290,5.000)$ \\
B22 & $(0.333,1.071,4.000)$ & $(1.000,1.000,1.000)$ & $(0.200,0.794,1.000)$ & $(0.250,0.694,3.000)$ & $(1.000,2.620,4.000)$ \\
B23 & $(0.250,1.200,4.000)$ & $(1.000,1.259,5.000)$ & $(1.000,1.000,1.000)$ & $(1.000,1.122,3.000)$ & $(1.000,2.448,4.000)$ \\
B24 & $(0.250,1.124,4.000)$ & $(0.333,1.441,4.000)$ & $(0.333,0.891,1.000)$ & $(1.000,1.000,1.000)$ & $(1.000,2.450,5.000)$ \\
B25 & $(0.200,0.437,1.000)$ & $(0.250,0.382,1.000)$ & $(0.250,0.408,1.000)$ & $(0.200,0.408,1.000)$ & $(1.000,1.000,1.000)$ \\
\hline
\end{tabular}

Table 14 Fuzzy pairwise comparison with respect to Green Industrial Development (C3)

\begin{tabular}{lllllll}
\hline & $\mathrm{C} 31$ & $\mathrm{C} 32$ & $\mathrm{C} 33$ & $\mathrm{C} 34$ & $\mathrm{C} 35$ & $\mathrm{C} 36$ \\
\hline $\mathrm{C} 31$ & $(1.000,1.000,1.000)$ & $(0.250,1.260,4.000)$ & $(0.250,0.891,4.000)$ & $(0.250,0.891,4.000)$ & $(1.000,1.781,5.000)$ & $(1.000,2.289,5.000)$ \\
$\mathrm{C} 32$ & $(0.250,0.794,4.000)$ & $(1.000,1.000,1.000)$ & $(0.250,0.742,1.000)$ & $(0.250,0.833,3.000)$ & $(1.000,1.816,4.000)$ & $(1.000,2.181,4.000)$ \\
C33 & $(0.250,1.122,4.000)$ & $(1.000,1.348,4.000)$ & $(1.000,1.000,1.000)$ & $(1.000,1.348,4.000)$ & $(1.000,1.905,4.000)$ & $(1.000,2.288,4.000)$ \\
C34 & $(0.250,1.122,4.000)$ & $(0.333,1.200,4.000)$ & $(0.250,0.742,1.000)$ & $(1.000,1.000,1.000)$ & $(1.000,1.816,4.000)$ & $(1.000,2.138,5.000)$ \\
C35 & $(0.200,0.561,1.000)$ & $(0.250,0.551,1.000)$ & $(0.250,0.525,1.000)$ & $(0.250,0.551,1.000)$ & $(1.000,1.000,1.000)$ & $(1.000,1.347,4.000)$ \\
C36 & $(0.200,0.437,1.000)$ & $(0.250,0.459,1.000)$ & $(0.250,0.437,1.000)$ & $(0.200,0.468,1.000)$ & $(0.250,0.742,1.000)$ & $(1.000,1.000,1.000)$ \\
\hline
\end{tabular}

Table 15 Fuzzy pairwise comparison with respect to Environmental Regulations (D4)

\begin{tabular}{llllll}
\hline & $\mathrm{D} 41$ & $\mathrm{D} 42$ & $\mathrm{D} 43$ & $\mathrm{D} 44$ & $\mathrm{D} 45$ \\
\hline $\mathrm{D} 41$ & $(1.000,1.000,1.000)$ & $(1.000,1.697,4.000)$ & $(1.000,2.038,4.000)$ & $(1.000,2.181,4.000)$ & $(1.000,2.620,4.000)$ \\
D42 & $(0.250,0.589,1.000)$ & $(1.000,1.000,1.000)$ & $(0.333,1.122,3.000)$ & $(1.000,1.000,1.000)$ & $(1.000,1.348,4.000)$ \\
D43 & $(0.250,0.491,1.000)$ & $(0.333,0.891,3.003)$ & $(1.000,1.000,1.000)$ & $(1.000,1.780,3.000)$ & $(1.000,1.347,4.000)$ \\
D44 & $(0.250,0.459,1.000)$ & $(1.000,1.000,1.000)$ & $(0.333,0.562,1.000)$ & $(1.000,1.000,1.000)$ & $(1.000,1.201,4.000)$ \\
D45 & $(0.250,0.382,1.000)$ & $(0.250,0.742,1.000)$ & $(0.250,0.742,1.000)$ & $(0.250,0.833,1.000)$ & $(1.000,1.000,1.000)$ \\
\hline
\end{tabular}

Table 16 Fuzzy pairwise comparison with respect to Resource Efficiency (E5)

\begin{tabular}{llllll}
\hline & E51 & E52 & E53 & E54 & E55 \\
\hline E51 & $(1.000,1.000,1.000)$ & $(1.000,2.181,4.000)$ & $(1.000,2.038,4.000)$ & $(1.000,2.450,5.000)$ & $(1.000,2.288,4.000)$ \\
E52 & $(0.250,0.459,1.000)$ & $(1.000,1.000,1.000)$ & $(0.333,0.891,1.000)$ & $(1.000,1.259,3.000)$ & $(1.000,1.347,4.000)$ \\
E53 & $(0.250,0.491,1.000)$ & $(1.000,1.122,3.003)$ & $(1.000,1.000,1.000)$ & $(1.000,1.201,4.000)$ & $(1.000,1.697,4.000)$ \\
E54 & $(0.200,0.408,1.000)$ & $(0.333,0.794,1.000)$ & $(0.250,0.833,1.000)$ & $(1.000,1.000,1.000)$ & $(1.000,1.122,3.000)$ \\
E55 & $(0.250,0.437,1.000)$ & $(0.250,0.742,1.000)$ & $(0.250,0.589,1.000)$ & $(0.333,0.891,1.000)$ & $(1.000,1.000,1.000)$ \\
\hline
\end{tabular}


Table 17 Fuzzy pairwise comparison with respect to Technological Initiatives and Innovation (F6)

\begin{tabular}{llllll}
\hline & F61 & F62 & F63 & F64 & F65 \\
\hline F61 & $(1.000,1.000,1.000)$ & $(1.000,1.512,4.000)$ & $(0.333,1.441,4.000)$ & $(0.333,1.441,4.000)$ & $(1.000,2.039,4.000)$ \\
F62 & $(0.250,0.661,1.000)$ & $(1.000,1.000,1.000)$ & $(1.000,1.201,4.000)$ & $(0.333,1.000,3.000)$ & $(1.000,2.290,4.000)$ \\
F63 & $(0.250,0.694,3.003)$ & $(0.250,0.833,1.000)$ & $(1.000,1.000,1.000)$ & $(1.000,1.259,3.000)$ & $(1.000,1.905,4.000)$ \\
F64 & $(0.250,0.694,3.003)$ & $(0.333,1.000,3.003)$ & $(0.333,0.794,1.000)$ & $(1.000,1.000,1.000)$ & $(1.000,1.201,4.000)$ \\
F65 & $(0.250,0.490,1.000)$ & $(0.250,0.437,1.000)$ & $(0.250,0.525,1.000)$ & $(0.250,0.833,1.000)$ & $(1.000,1.000,1.000)$ \\
\hline
\end{tabular}

Table 18 Fuzzy pairwise comparison under Green Energy Production and Consumption Practices (G7)

\begin{tabular}{llll}
\hline & G71 & G72 & G73 \\
\hline G71 & $(1.000,1.000,1.000)$ & $(1.000,1.698,4.000)$ & $(1.000,2.377,6.000)$ \\
G72 & $(0.250,0.589,1.000)$ & $(1.000,1.000,1.000)$ & $(1.000,1.122,3.000)$ \\
G73 & $(0.167,0.421,1.000)$ & $(0.333,0.891,1.000)$ & $(1.000,1.000,1.000)$ \\
\hline
\end{tabular}

Table 19 Fuzzy pairwise comparison with respect to Blue-Green Infrastructure Development (H8)

\begin{tabular}{llllll}
\hline & H81 & H82 & H83 & H84 & H85 \\
\hline H81 & $(1.000,1.000,1.000)$ & $(1.000,1.442,4.000)$ & $(0.250,1.070,4.000)$ & $(0.250,0.954,4.000)$ & $(1.000,2.289,5.000)$ \\
H82 & $(0.250,0.693,1.000)$ & $(1.000,1.000,1.000)$ & $(0.250,0.742,1.000)$ & $(0.250,0.833,3.000)$ & $(1.000,1.817,4.000)$ \\
H83 & $(0.250,0.935,4.000)$ & $(1.000,1.348,4.000)$ & $(1.000,1.000,1.000)$ & $(0.333,1.201,4.000)$ & $(1.000,2.288,4.000)$ \\
H84 & $(0.250,1.048,4.000)$ & $(0.333,1.200,4.000)$ & $(0.250,0.833,3.003)$ & $(1.000,1.000,1.000)$ & $(1.000,2.038,4.000)$ \\
H85 & $(0.200,0.437,1.000)$ & $(0.250,0.550,1.000)$ & $(0.250,0.437,1.000)$ & $(0.250,0.491,1.000)$ & $(1.000,1.000,1.000)$ \\
\hline
\end{tabular}

Table 20 Fuzzy pairwise comparison with respect to Pollution Control and Waste Management (I9)

\begin{tabular}{lllll}
\hline & $\mathrm{I} 91$ & $\mathrm{I} 92$ & $\mathrm{I} 93$ & $\mathrm{I} 94$ \\
\hline $\mathrm{I} 91$ & $(1.000,1.000,1.000)$ & $(0.333,1.512,5.000)$ & $(1.000,1.998,3.000)$ & $(1.000,1.817,4.000)$ \\
$\mathrm{I} 92$ & $(0.200,0.661,3.003)$ & $(1.000,1.000,1.000)$ & $(1.000,1.122,3.000)$ & $(0.250,1.259,4.000)$ \\
$\mathrm{I} 93$ & $(0.333,0.501,1.000)$ & $(0.333,0.891,1.000)$ & $(1.000,1.000,1.000)$ & $(0.333,0.891,1.000)$ \\
$\mathrm{I} 94$ & $(0.250,0.550,1.000)$ & $(0.250,0.794,4.000)$ & $(1.000,1.122,3.003)$ & $(1.000,1.000,1.000)$ \\
\hline
\end{tabular}

Table 21 Fuzzy pairwise comparison with respect to Labor Policies (J10)

\begin{tabular}{lllll}
\hline & J101 & J102 & J103 & J104 \\
\hline J101 & $(1.000,1.000,1.000)$ & $(1.000,1.697,4.000)$ & $(0.333,1.543,4.000)$ & $(0.333,1.347,4.000)$ \\
J102 & $(0.250,0.589,1.000)$ & $(1.000,1.000,1.000)$ & $(0.250,0.833,1.000)$ & $(0.250,1.177,3.000)$ \\
J103 & $(0.250,0.648,3.003)$ & $(1.000,1.200,4.000)$ & $(1.000,1.000,1.000)$ & $(1.000,1.122,3.000)$ \\
J104 & $(0.250,0.742,3.003)$ & $(0.333,0.850,4.000)$ & $(0.333,0.891,1.000)$ & $(1.000,1.000,1.000)$ \\
\hline
\end{tabular}




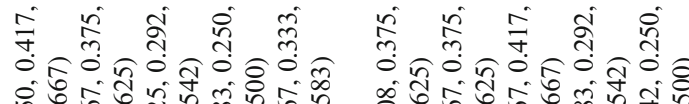

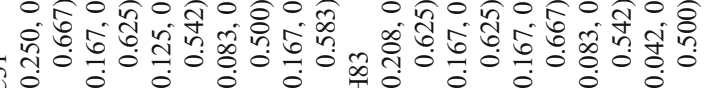
ऊ

तิ

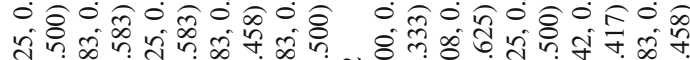
थ ती

苛 ली

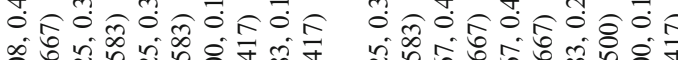
幽过

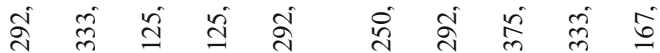

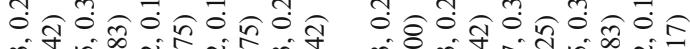

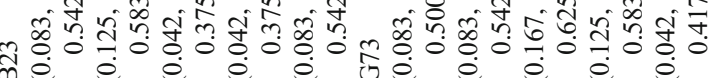

ปิ

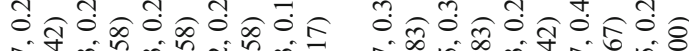

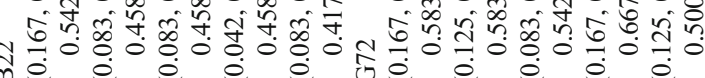

तิ तิ तิ

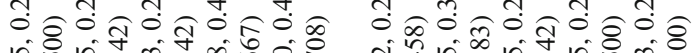
च

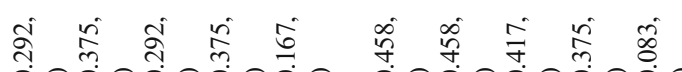

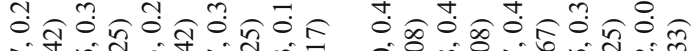

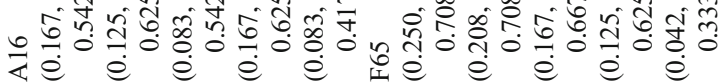

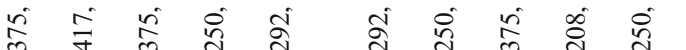

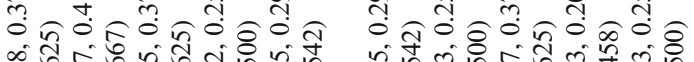
त̂.

ल

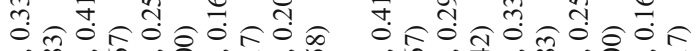

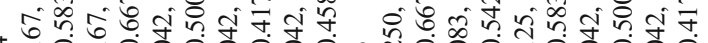

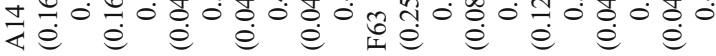

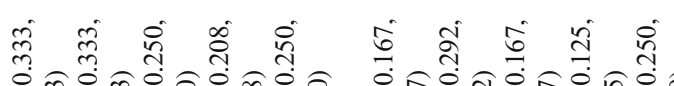

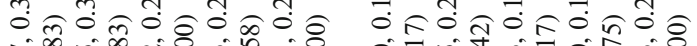
«

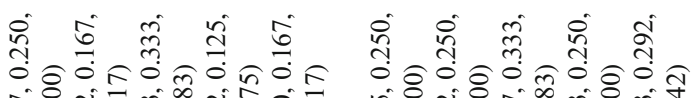

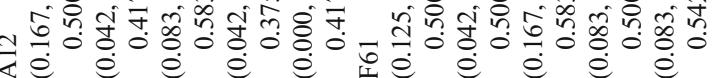

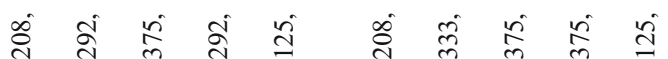

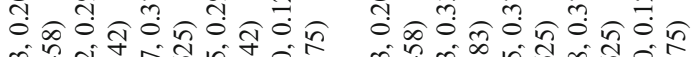

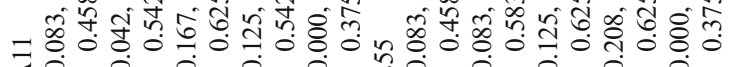

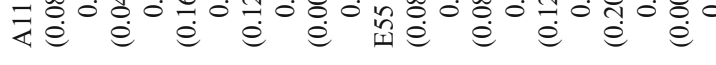

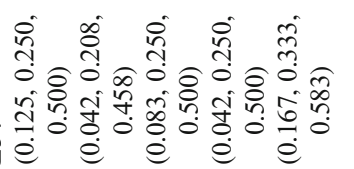

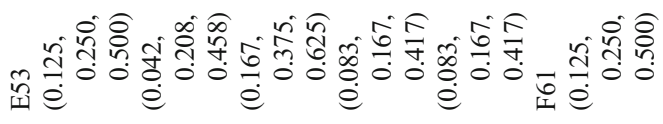

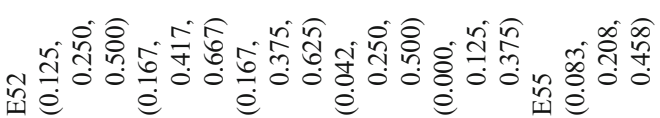

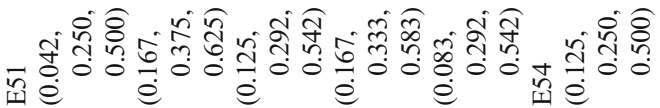

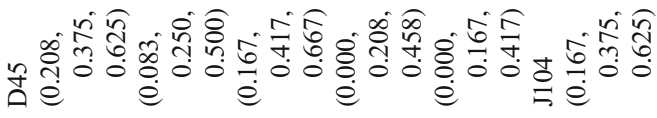

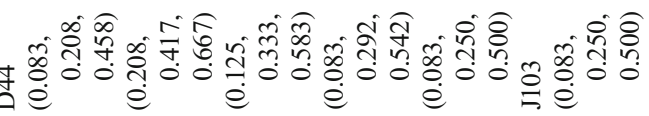

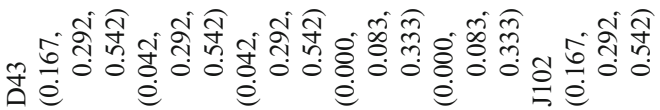

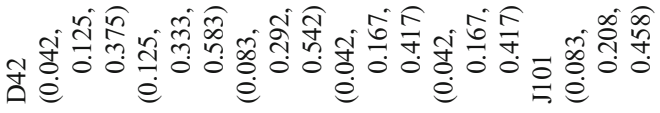

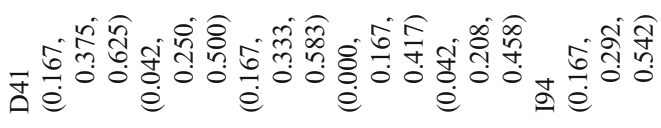

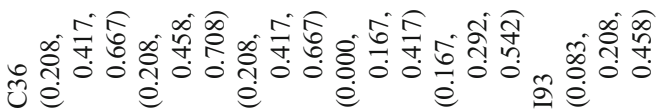

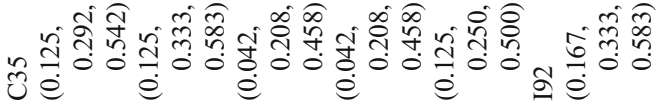

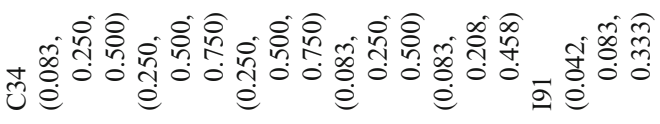

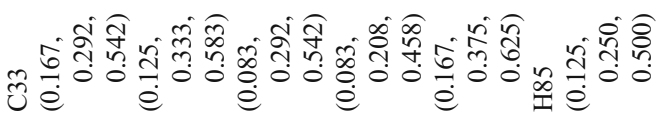

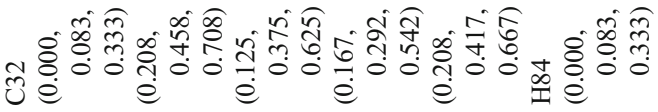

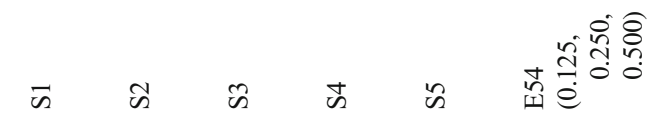




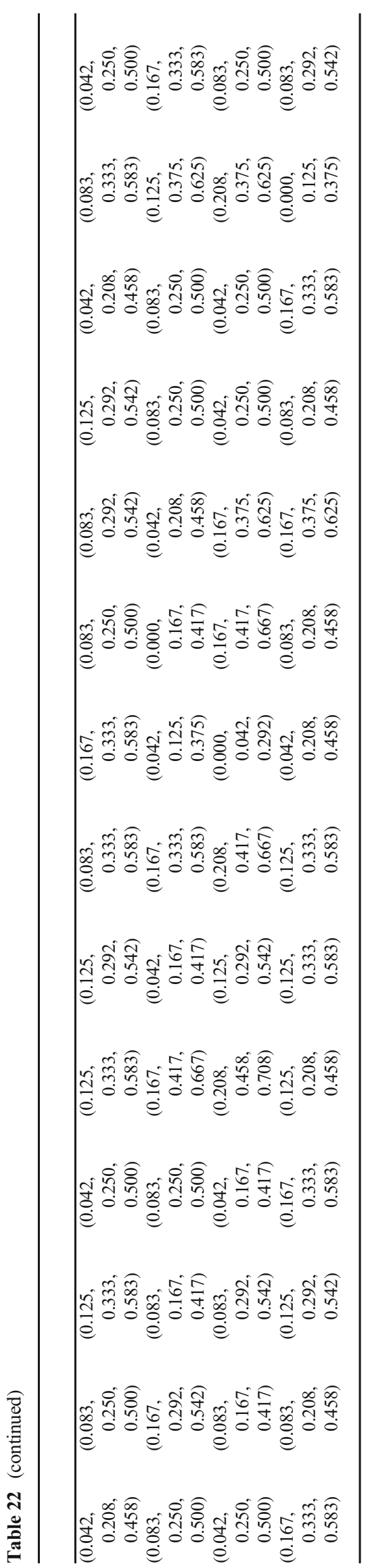




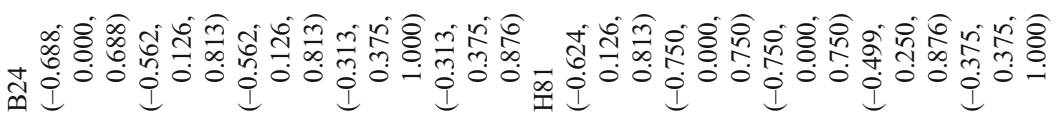

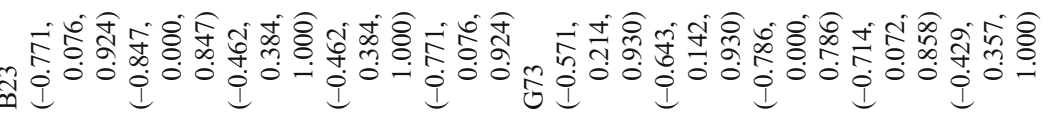
$\underset{\substack{\sim \\ \frac{0}{\circ}}}{\frac{\pi}{\sigma}}$
|

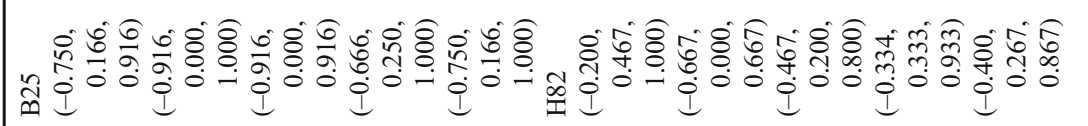

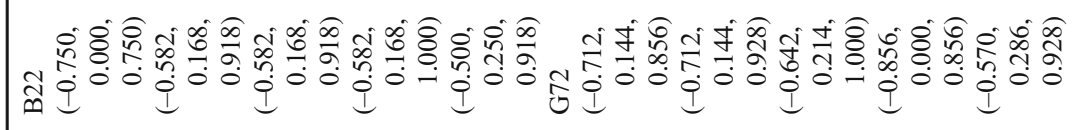

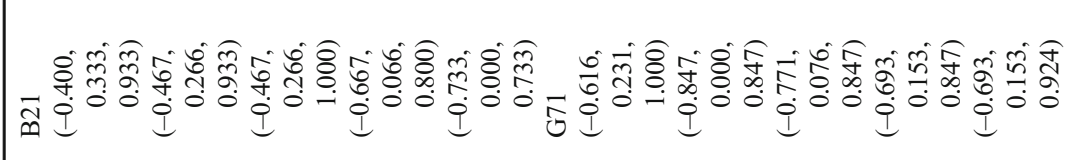

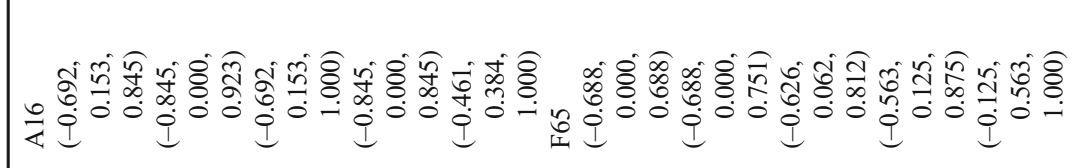

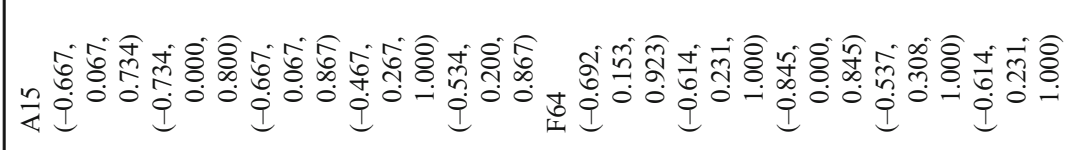

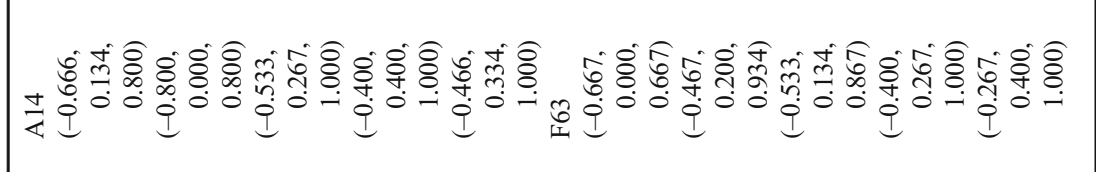

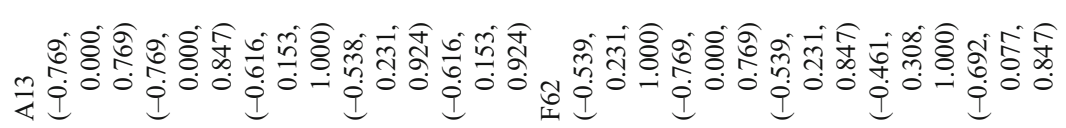

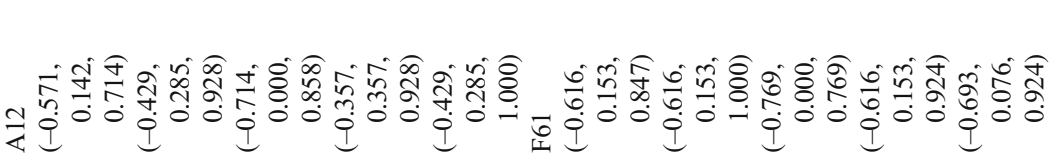

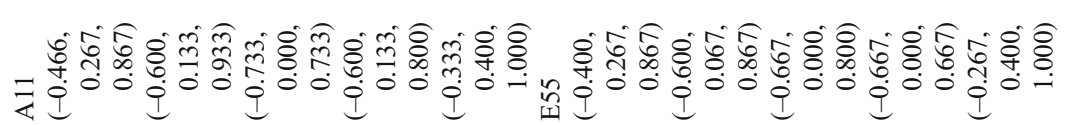

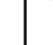

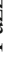

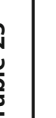

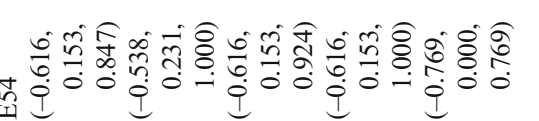

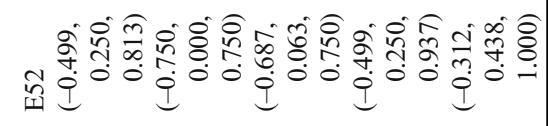

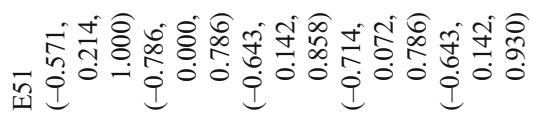

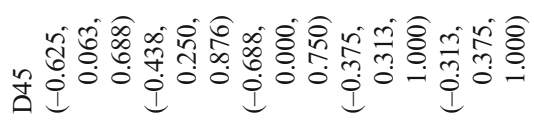

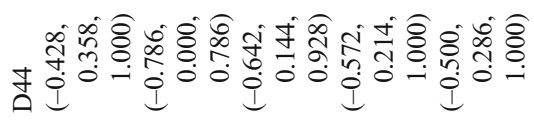

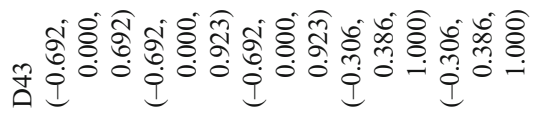

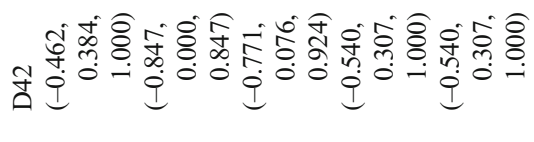

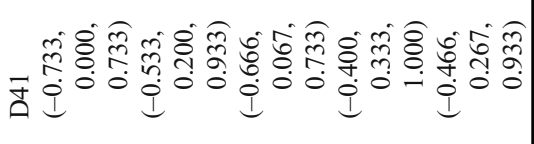

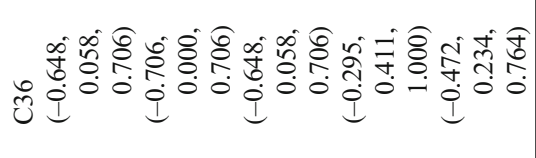

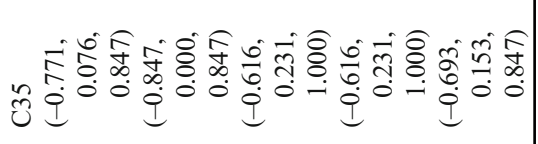

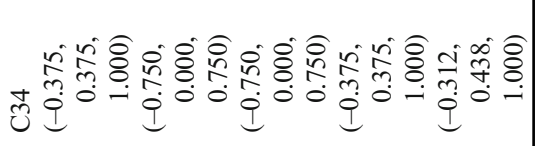

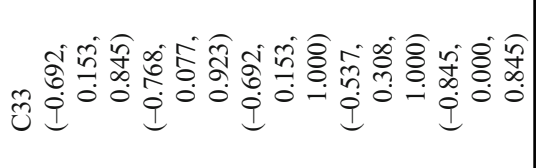

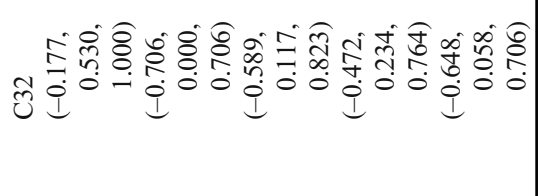
政 के है

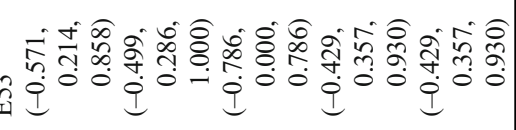




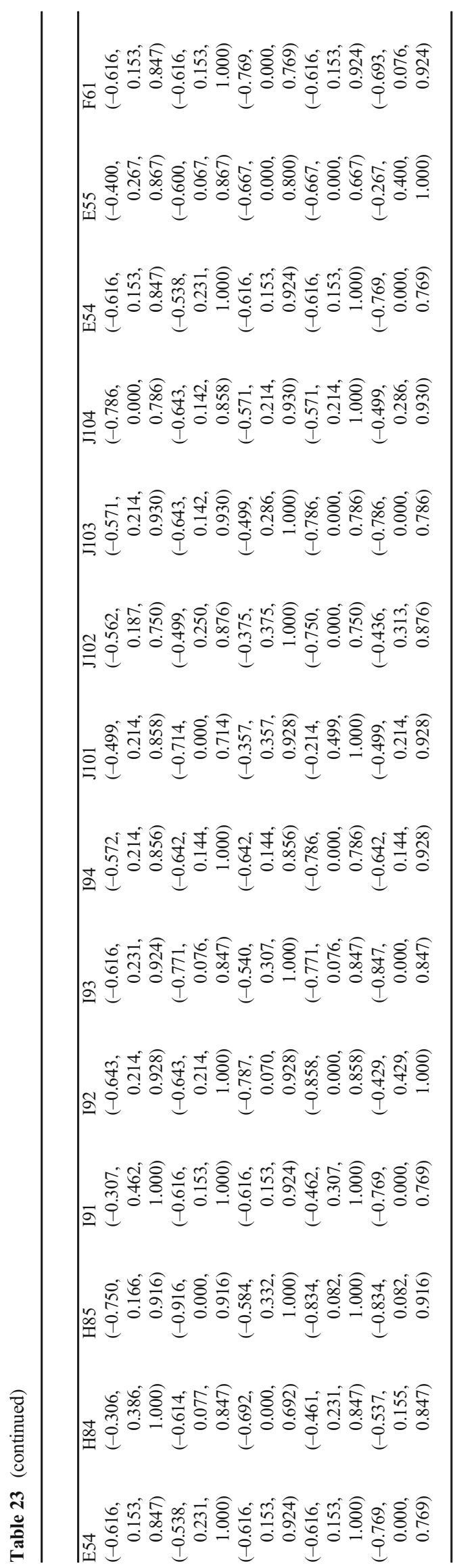


Table 24 The fuzzy values $S, R$, and $Q$

\begin{tabular}{llll}
\hline & Fuzzy $R$ & Fuzzy $S$ & Fuzzy $Q$ \\
\hline S1 & $(-0.004,0.011,0.021)$ & $(-0.596,0.179,0.860)$ & $(-0.862,0.112,0.978)$ \\
S2 & $(-0.009,0.006,0.021)$ & $(-0.684,0.090,0.875)$ & $(-0.978,0.000,0.982)$ \\
S3 & $(-0.007,0.008,0.021)$ & $(-0.645,0.129,0.883)$ & $(-0.941,0.046,0.985)$ \\
S4 & $(-0.005,0.010,0.021)$ & $(-0.555,0.219,0.931)$ & $(-0.863,0.114,1.000)$ \\
S5 & $(-0.003,0.012,0.021)$ & $(-0.537,0.237,0.927)$ & $(-0.826,0.142,0.999)$ \\
\hline
\end{tabular}

Author contribution Conceptualization, Shuangliang Yao. Data curation, Shuangliang Yao. Formal analysis, Shuangliang Yao. Investigation, Shuangliang Yao. Methodology, Shuangliang Yao. Validation, Shuangliang Yao. Writing — original draft, Shuangliang Yao. Writingreview and editing, Shuangliang Yao.

Funding This work was supported by the Humanities and Social Sciences Research Fund Project of the Ministry of Education, "Research on the Effect of China's OFDI Marginal Industry Transfer under the Belt and Road Win-Win Strategy" (17YJA790020); Schoollevel Scientific Research Fund Project: "Research on China's Ecological Welfare Performance Evaluation and Improvement PATH from the perspective of High Quality Development" (CKJA201905).

Data Availability All data generated or analyzed during this study are included in this manuscript.

\section{Declarations}

Ethical approval It is certified that all the authors have complied with ethical requirements.

Consent to participate All the authors participated equally in writing the manuscript.

Consent for publication This manuscript is neither submitted anywhere nor under consideration for publication elsewhere.

Competing interests The authors declare no competing interests.

\section{References}

Ahmed W, Tan Q, Shaikh GM, Waqas H, Kanasro NA, Ali S, Solangi YA (2020a) Assessing and prioritizing the climate change policy objectives for sustainable development in Pakistan. Symmetry (Basel) 12:1203. https://doi.org/10.3390/sym12081203

Ahmed W, Tan Q, Solangi YA, Ali S (2020b) Sustainable and special economic zone selection under fuzzy environment: a case of Pakistan. Symmetry 12:242. https://doi.org/10.3390/ SYM12020242

Ali S (2013) The small and medium enterprises and poverty in Pakistan: an empirical analysis. Eur J Bus Econ 8:25-30. https://doi.org/10. 12955/ejbe.v8i2.376
Ali S, Xu H, Ahmed W, Ahmad N, Solangi YA (2019) Metro design and heritage sustainability: conflict analysis using attitude based on options in the graph model. Environ Dev Sustain 1-22:3839-3860. https://doi.org/10.1007/s10668-019-00365-w

Ali Shah SA, Longsheng C, Solangi YA, Ahmed M, Ali S (2020) Energy trilemma based prioritization of waste-to-energy technologies: implications for post-COVID-19 green economic recovery in Pakistan. J Clean Prod 284:124729. https://doi.org/10.1016/j.jclepro.2020. 124729

Bohong L, Ling L, Chunyu Y, 2016. Gender (in)equality and China's economic transition, In: Revisiting Gender Inequality. Palgrave Macmillan US, pp. 21-57. https://doi.org/10.1057/ 97811375508042

Cao W, Zhang Y, Qian P (2019) The effect of innovation-driven strategy on green economic development in china - an empirical study of smart cities. Int J Environ Res Public Health 16:1520. https://doi. org/10.3390/ijerph16091520

Chan HK, Yee RWY, Dai J, Lim MK (2016) The moderating effect of environmental dynamism on green product innovation and performance. Int J Prod Econ 181:384-391. https://doi.org/10.1016/j.ijpe. 2015.12.006

Chu Z, Liu C, Li G, Guan K (2018) Sustainable development of the economic circle around Beijing: a view of regional economic disparity. Sustain. 10:3691. https://doi.org/10.3390/su10103691

CLP, 2020. What's going on in China: recycling's rise to power - closed loop partners [WWW Document]. Closed Loop Partners.

Feng Z, Chen W (2018) Environmental regulation, green innovation, and industrial green development: an empirical analysis based on the spatial Durbin model. Sustain. 10:14485. https://doi.org/10.3390/ su10010223

Fengshi, W., 2009. Environmental activism and civil society in China: fifteen years in review, 1994-2008, Harward-Yenching Institute Working Paper Series.

Forster PM, Forster HI, Evans MJ, Gidden MJ, Jones CD, Keller CA, Lamboll RD, Le Quéré C, Rogelj J, Rosen D, Schleussner CF, Richardson TB, Smith CJ, Turnock ST (2020) Current and future global climate impacts resulting from COVID-19. Nat Clim Chang 10:913-919. https://doi.org/10.1038/s41558-020-0883-0

Fu Y, Dong N, Ge Q, Xiong F, Gong C (2020) Driving-paths of green buildings industry ( GBI ) from stakeholders ' green behavior based on the network analysis. J Clean Prod 273:122883. https://doi.org/ 10.1016/j.jclepro.2020.122883

Gogus O, Boucher TO (1998) Strong transitivity, rationality and weak monotonicity in fuzzy pairwise comparisons. Fuzzy Sets Syst 94: 133-144. https://doi.org/10.1016/S0165-0114(96)00184-4

Green Growth, 2018. Resource efficiency for sustainable development: key messages for the G20 | Green Growth Knowledge Platform 
[WWW Document]. United Nations Environ Program (UN Environ. Int. Resour. Panel.

GTR, 2018. Global transmission report : update on China's power sector: focus on clean energy mix and grid integration [WWW Document]. Glob. Transm. Rep. .

Guo Y, Xia X, Zhang S, Zhang D (2018) Environmental regulation, government $\mathrm{R} \& \mathrm{D}$ funding and green technology innovation: evidence from China provincial data. Sustain. 10:940. https://doi.org/ 10.3390/su10040940

Henry MS, Bazilian MD, Markuson C (2020) Just transitions: histories and futures in a post-COVID world. Energy Res Soc Sci 68:101668. https://doi.org/10.1016/j.erss.2020.101668

Hesselink LXW, Chappin EJL (2019) Adoption of energy efficient technologies by households - barriers, policies and agent-based modelling studies. Renew Sust Energ Rev 99:29-41. https://doi.org/10. 1016/j.rser.2018.09.031

Hou Y, Iqbal W, Shaikh GM, Iqbal N, Solangi YA, Fatima A (2019) Measuring energy efficiency and environmental performance: a case of South Asia. Processes 7:325. https://doi.org/10.3390/pr7060325

ICMA, (2019). Growing a Green Economy / icma.org [WWW Document].

IIED, 2020. Why social inclusion matters for green growth | International Institute for Environment and Development [WWW Document]. Int Inst Environ Dev.

ILO, (2015). Gender Equality and Green Jobs.

ILO, (2011). Promoting Decent Work in a Green Economy. Int Labor Organ.

John H, Marrs C, Neubert M, Alberico S, Bovo G, 2019. Green infrastructure handbook.

Kaganski S, Majak J, Karjust K, 2018. Fuzzy AHP as a tool for prioritization of key performance indicators, in: Procedia CIRP. https://doi. org/10.1016/j.procir.2018.03.097

Kul C, Zhang L, Solangi YA (2020) Assessing the renewable energy investment risk factors for sustainable development in Turkey. J Clean Prod 276:124164. https://doi.org/10.1016/j.jclepro.2020. 124164

Laurisz N (2019) The role of stakeholders in development of social economy organizations in Poland: an integrative approach. Adm Sci 9: 74. https://doi.org/10.3390/admsci 9040074

Liao M, Wang Y (2019) China's energy consumption rebound effect analysis based on the perspective of technological progress. Sustain. 11. https://doi.org/10.3390/su11051461

Liu HC, Mao LX, Zhang ZY, Li P (2013) Induced aggregation operators in the VIKOR method and its application in material selection. Appl Math Model 37:6325-6338. https://doi.org/10.1016/j.apm.2013.01. 026

Liu L, Fryd O, Zhang S (2019) Blue-green infrastructure for sustainable urban stormwater management-lessons from six municipality-led pilot projects in Beijing and Copenhagen. Water 11:2024. https:// doi.org/10.3390/w11102024

Liu Y, Zhu J, Li EY, Meng Z, Song Y (2020) Environmental regulation, green technological innovation, and eco-efficiency: the case of Yangtze river economic belt in China. Technol Forecast Soc Change 155:119993. https://doi.org/10.1016/j.techfore.2020. 119993

Lorente DB, Álvarez-Herranz A (2016) Economic growth and energy regulation in the environmental Kuznets curve. Environ Sci Pollut Res 23:16478-16494. https://doi.org/10.1007/s11356-016-6773-3

Luo Y, Salman M, Lu Z (2021) Heterogeneous impacts of environmental regulations and foreign direct investment on green innovation across different regions in China. Sci Total Environ 759:143744. https:// doi.org/10.1016/j.scitotenv.2020.143744

Ma J, Wang J, Szmedra P (2019) Economic efficiency and its influencing factors on urban agglomeration-an analysis based on China's top 10 urban agglomerations. Sustain. 11:1-19. https://doi.org/10.3390/ su11195380
Miao C, Fang D, Sun L, Luo Q (2017) Natural resources utilization efficiency under the influence of green technological innovation. Resour Conserv Recycl 126:153-161. https://doi.org/10.1016/j. resconrec.2017.07.019

OECD (2020) Towards sustainable land use: aligning biodiversity, climate and food policies. OECD. https://doi.org/10.1787/3809b6a1en

OECD, 2012. Enabling local green growth: addressing climate change effects on employment and local development.

Oldekop JA, Horner R, Hulme D, Adhikari R, Agarwal B, Alford M, Bakewell O, Banks N, Barrientos S, Bastia T, Bebbington AJ, Das U, Dimova R, Duncombe R, Enns C, Fielding D, Foster C, Foster T, Frederiksen T, Gao P, Gillespie T, Heeks R, Hickey S, Hess M, Jepson N, Karamchedu A, Kothari U, Krishnan A, Lavers T, Mamman A, Mitlin D, Monazam Tabrizi N, Müller TR, Nadvi K, Pasquali G, Pritchard R, Pruce K, Rees C, Renken J, Savoia A, Schindler S, Surmeier A, Tampubolon G, Tyce M, Unnikrishnan V, Zhang YF (2020) COVID-19 and the case for global development. World Dev 134:105044. https://doi.org/10.1016/j.worlddev. 2020.105044

Opricovic S, Tzeng GH (2007) Extended VIKOR method in comparison with outranking methods. Eur J Oper Res 178:514-529. https://doi. org/10.1016/j.ejor.2006.01.020

Pesce M, Tamai I, Guo D, Critto A, Brombal D, Wang X, Cheng H, Marcomini A (2020) Circular economy in China: translating principles into practice. Sustain. 12:1-31. https://doi.org/10.3390/ su12030832

Pociovălișteanu D, Novo-Corti I, Aceleanu M, Șerban A, Grecu E (2015) Employment policies for a green economy at the European Union level. Sustainability 7:9231-9250. https://doi.org/10.3390/ su7079231

Prud'homme D, Zhang T, 2019. China's intellectual property regime for innovation, 1st ed, China's Intellectual Property Regime for Innovation. Springer International Publishing. https://doi.org/10. 1007/978-3-030-10404-7_1

Qu J, Wang H, Wang K, Yu G, Ke B, Yu HQ, Ren H, Zheng X, Li J, Li WW, Gao S, Gong H (2019) Municipal wastewater treatment in China: development history and future perspectives. Front Environ Sci Eng 13:88. https://doi.org/10.1007/s11783-019-1172-x

Saaty TL (1990) The analytic hierarchy process. Eur J Oper Res 45:378. https://doi.org/10.1016/0377-2217(90)90209-t

Shukla RK, Garg D, Agarwal A (2014) An integrated approach of Fuzzy AHP and Fuzzy TOPSIS in modeling supply chain coordination. Prod Manuf Res 2:415-437. https://doi.org/10.1080/21693277. 2014.919886

Shumaiza, Akram M, Al-Kenani AN, Alcantud JCR (2019) Group decision-making based on the VIKOR method with trapezoidal bipolar fuzzy information. Symmetry (Basel) 11:1-21. https://doi.org/ 10.3390/sym 11101313

Solangi YA, Shah SAA, Zameer H, Ikram M, Saracoglu BO (2019a) Assessing the solar PV power project site selection in Pakistan: based on AHP-fuzzy VIKOR approach. Environ Sci Pollut Res 26:30286-30302. https://doi.org/10.1007/s11356-019-06172-0

Solangi YA, Tan Q, Khan MWA, Mirjat NH, Ahmed I (2018) The selection of wind power project location in the Southeastern Corridor of Pakistan: a factor analysis, AHP, and fuzzy-TOPSIS application. Energies 11:1940. https://doi.org/10.3390/en1 1081940

Solangi YA, Tan Q, Mirjat NH, Ali S (2019b) Evaluating the strategies for sustainable energy planning in Pakistan: an integrated SWOTAHP and Fuzzy-TOPSIS approach. J Clean Prod 236:117655. https://doi.org/10.1016/j.jclepro.2019.117655

Solangi YA, Tan Q, Mirjat NH, Valasai GD, Khan MWA, Ikram, M., 2019c. An integrated Delphi-AHP and fuzzy TOPSIS approach toward ranking and selection of renewable energy resources in Pakistan. Processes 7. https://doi.org/10.3390/pr7020118 
Thorpe D (2020) How investing in the green economy is the best way to post-Covid-19 economic recovery. Proc Inst Civ Eng Civ Eng 173: 100. https://doi.org/10.1680/jcien.2020.173.3.100

Tracy EF, Shvarts E, Simonov E, Babenko M (2017) China's new Eurasian ambitions: the environmental risks of the Silk Road Economic Belt. Eurasian Geogr Econ 58:56-88. https://doi.org/10. $1080 / 15387216.2017 .1295876$

UNEP, 2011. Towards a green economy: pathways to sustainable development and poverty eradication - a synthesis for policy makers, towards a GREEN economy.

UNIDO (2010) Green industry for a low-carbon future. The United Nations Industrial Development Organization (UNIDO), Vienna

Wang C, Wang Y (2020) In search of open and inclusive arenas: transnational practice of communicative planning in Yongtai. China Habitat Int 106:102288. https://doi.org/10.1016/j.habitatint.2020. 102288

Wang Y, Xu L, Solangi YA (2020) Strategic renewable energy resources selection for Pakistan: based on SWOT-Fuzzy AHP approach. Sustain Cities Soc 52:101861. https://doi.org/10.1016/j.scs.2019. 101861

Wang Z, Wang X, Liang L (2019) Green economic efficiency in the Yangtze River Delta: spatiotemporal evolution and influencing factors. Ecosyst Heal Sustain 5:20-35. https://doi.org/10.1080/ 20964129.2018.1559000

Weng X, Dong Z, Wu Q, Qin Y, 2015. China's path to a green economy: decoding China's green economy concepts and policies. IIED Contry Report, IIED: Londong.

Yang G, Calhoun C (2007) Media, civil society, and the rise of a green public sphere in China. China Inf 21:211-236. https://doi.org/10. 1177/0920203X07079644
Yu S, Sial MS, Tran DK, Badulescu A, Thu PA, Sehleanu M (2020) Adoption and implementation of sustainable development goals (SDGs) in China-Agenda 2030. Sustain. 12:1-16. https://doi.org/ $10.3390 /$ SU12156288

Yuan B, Xiang Q (2018) Environmental regulation, industrial innovation and green development of Chinese manufacturing: based on an extended CDM model. J Clean Prod 176:895-908. https://doi.org/10. 1016/j.jclepro.2017.12.034

Zhou Y, Xu L, Shaikh GM (2019) Evaluating and prioritizing the green supply chain management practices in Pakistan: based on Delphi and fuzzy AHP approach. Symmetry (Basel) 11:1346. https://doi. org/10.3390/sym11111346

Zhu J, Fan C, Shi H, Shi L (2019a) Efforts for a circular economy in China: a comprehensive review of policies. J Ind Ecol 23:110-118. https://doi.org/10.1111/jiec.12754

Zhu X, Zhang Y (2019) Diffusion of marketization innovation with administrative centralization in a multilevel system: evidence from China. J Public Adm Res Theory 29:133-150. https://doi.org/10. 1093/jopart/muy034

Zhu Z, Lang W, Tao X, Feng J, Liu K (2019b) Exploring the quality of urban green spaces based on urban neighborhood green index-a case study of Guangzhou city. Sustain. 11:1-17. https://doi.org/10.3390/ su11195507

Zhuang T (2017) Stakeholders ' expectations in urban renewal projects in China : a key step towards sustainability. Sustainability 2017:1640. https://doi.org/10.3390/su9091640

Publisher's note Springer Nature remains neutral with regard to jurisdictional claims in published maps and institutional affiliations. 